УДК 549:552.323.6, 549:553.491

\title{
ГЕОЛОГИЯ И МИНЕРАЛОГИЯ КАРБОНАТИТОВ ЛИНЕЙНО-ТРЕЩИННОГО ТИПА РУДОПРОЯВЛЕНИЯ МАЙКЕ МАЯТАССКОГО РУДНОГО РАЙОНА (СЕВЕРНЫЙ УЛЫТАУ)
}

\author{
Степанец Владимир Григорьевич1, \\ wladimir@stepanez.de
}

\section{Левин Владимир Леонидович2,} levin_v@inbox.ru

ЛиЕлена Сергеевна ${ }^{3}$, li_elena.kstu@mail.ru

\author{
Бекенова Галия Кабешовна², \\ bekenova@mail.ru
}

Жуков Николай Мефодьевич2, nik.zhukov.33@mail.ru

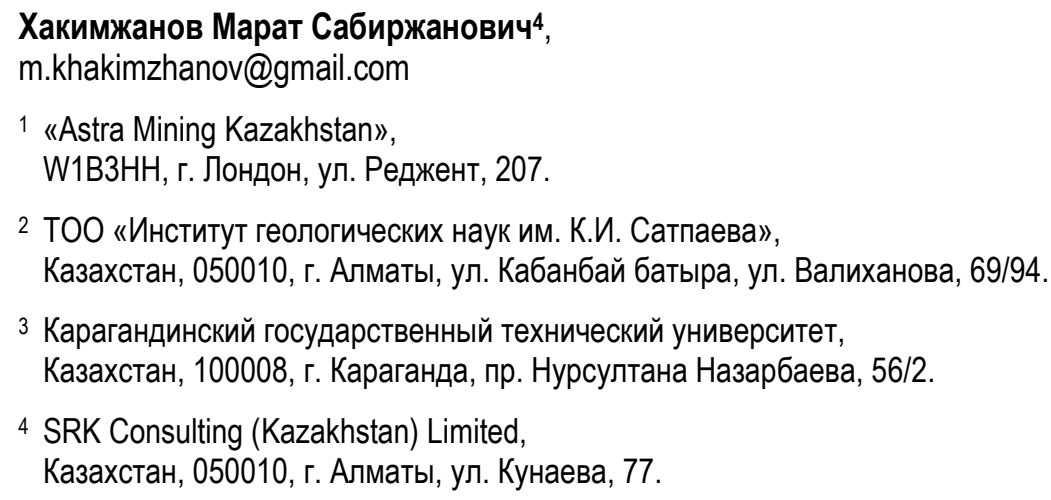

Актуальность исследования заключается в том, что проведенные детальные минералогические исследования с упором на электроннозондовый микроанализ дают информацию о составе руд и форме нахождения благородных металлов (группы платины), редких и редкоземельных элементов, что может значительно повлиять на экономическую ценность рудопроявления Майке.

Цель: определить распределение и формы нахождения благородных, редкоземельных и редких металлов в поликомпонентных медноколчеданных рудах проявления Майке.

объекты: метасоматиты линейно-трещинного типа и генетически связанные с ними медноколчеданные руды на правобережье реки Майке в пределах Маятасского рудного поля.

Методы. Состав медноколчеданных руд и породообразующих минералов метасоматитов был изучен в лабораториях минералогии и физических и химических методов исследований ТОО «ИГН им. К.И. Сатпаева» (2. Алматы). Элементный состав определен методом электроннозондового микроанализа на JCXA 733 с применением энергодисперсионного спектрометра INCA ENERGY. Проведены атомно-эмиссионный полуколичественный спектральный анализ, рентгенодифрактометрический и термический анализы.

Результаты. Рассмотрены основные критерии петрографиии и минералогии метасоматитов линейно-трещинного типа и генетически связанных с ними медноколчеданных руд, впервые выделенных в пределах Маятасского рудного района. Доказывается, что основные рудные тела медного колчедана локализуется в составе квари-рутил-сидерит-хлоритовых и сидеритмусковит-хлоритовых сланцах, являющихся составной частью силицит-карбонат-углеродистого комплекса. На основании детальных минералогических исследований показано, что медноколчеданные руды являются источниками платиноидов, редкоземельных элементов и рения. В составе медноколчеданных руд проявления Майке выделены виоларит, пирит, сфалерит, пирротин, микровключения кобальтина, никелистого кобальтина, феррокобальтина, герсдорфита, теллурида серебра, акантита, теллурида свинца, галенита, тестибиопалладита, висмутистого тестибиопалладита, мелонита, вавринита. Показано, что зональный никелистый кобальтин является источником платиноидов (Pt, Ir, Ru, Rh, Os), образующих поликомпонентные твердые растворы. Рений входит в состав сульфридов меди, железа, никеля, свинца и висмута. Теллур был обнаружен в составе теллурида серебра, теллурида свинца, тестибиопалладита, мелонита и вавринита. Эрбий встречен в составе незонального никелистого кобальтина и виоларита. Кадмий обнаружен в виде изоморфрной примеси только в сфралерите. Элементы цериевой (легкие - La, Ce, Pr, Nd, Sm) подгруппы и Y входят с состав фоосфатов, фтторфосфратов и являются источником образования водных фосфратов в зоне окисления медноколчеданных руд проявления Майке.

\section{Ключевые слова:}

Улытау, карбонатиты, медноколчеданные руды, сульфриды, арсениды, антимониды, минералы рения. 


\section{Введение}

Рудопроявление Майке располагается в пределах Маятасского рудного района к северо-востоку от поселка Маятас в бассейне одноименной реки, впадающей в реку Кара-Тургай Северного Улытау (рис. 1).

Литогеохимическая аномалия в пределах контура рудопроявления Майке имеет субмеридиональное простирание до 4,0 км при ширине от 20 до 400 м. Минерализованная зона на глубине 120 м выклинивается и в разрезе имеет форму морковки, мощность которой на поверхности достигает более 30 м при субмеридиональном простирании круто (70-80) погружается на восток. Зона минерализации с медноколчеданными рудами мощностью не более 35 см приурочена к выходам графит-кварц-рутил-сидеритмусковит-хлоритовым, которые являются составной частью графит-кварц-мусковит-полевошпат-хлоритовой толщи, исторически выделяемой в раннепротерозойскую аралбайскую серию [1]. К выходам пород аралбайской серии пространственно и генетически приурочены зоны минерализации линейно-трещинного типа. Сульфидные медно-цинк-свинцовые руды с платиноидами и редкоземельными элементами и свинцовые руды с редкоземельными элементами приурочены к углеродисто-карбонатным сланцам, а медноколчеданные руды с платиноидами и редкоземельными элементами обнаружены в разрезе кварц-рутилсидеритовых сланцев, их геохимическая специализация, как и природа углеродистого материала, не исключает их сопоставления с карбонатитами.

\section{Материал и методика исследования}

Для исследования нами был использован керн со скважины № п-10, предоставленный компанией «Маятас», которая на протяжении последних десяти лет проводит поисково-разведочные работы в пределах Маятасского рудного района. Из распила керна для детальных минералого-петрографических исследований было изготовлено четыре аншлифа (рис. 2).

Минералогическое исследование медноколчеданных руд и породообразующих минералов метасоматитов проводилось в лабораториях минералогии и физических и химических методов исследований ТОО «ИГН им. К.И. Сатпаева» (г. Алматы). Элементный состав изучался с помощью энергодисперсионного спектрометра INCA ENERGY, фирмы OXFORD INSTRUMENTS (Англия), установленного на электронно-зондовый микроанализатор Superprobe 733, фирмы JEOL (Япония) при ускоряющем напряжении 25 кВ, токе зонда 25 нА, диаметре зонда 1-2 мкм. В качестве образцов сравнения при анализе сульфидов использовали: для МПГ - чистые металлы, для РЗЭ (А) - искусственные соединения (A) $\mathrm{PO}_{4}$, для $\mathrm{Fe}, \mathrm{Cu}, \mathrm{S}-\mathrm{CuFeS}_{2}$, для $\mathrm{Pb}-\mathrm{PbS}$, для $\mathrm{Zn}-$ $\mathrm{ZnS}$, для остальных элементов - чистые металлы. Результаты анализов нормировали на 100 \%. Все фото были выполнены в режиме обратно-рассеянных электронов, в котором контраст на изображении зависит от среднего атомного номера фазы $\bar{Z}$. Чем больше $\bar{Z}$, т. е. чем больше тяжёлых элементов, тем светлее эта фаза на изображении.
Атомно-эмиссионный полуколичественный спектральный анализ проводился на дифракционном спектрографе ДФС-13 с дифракционной решеткой 500 штрихов на мм (аналитик к.х.н. Т.А. Озерова). Обратная линейная дисперсия прибора составляла 0,4 нм/мм, разрешающая сила спектрографа близка к теоретическому значению и составляла 720000 . В качестве источника возбуждения спектров использовалась дуга электрического тока силой 14 А. Спектры фотографировались на фотопластинки ПФС-03 в ультрафиолетовой области.

На автоматизированном дифрактометре ДРОН-3 с $\mathrm{CuK}_{\alpha}$-излучением, $\beta$-фильтр. Условия съемки дифрактограмм: $U=35$ кВ; $I=20 \mathrm{мA}$; съемка $\theta-2 \theta$; детектор 2 град/мин. Рентгенофазовый анализ на полуколичественной основе выполнен по дифрактограммам порошковых проб с применением метода равных навесок и искусственных смесей. Определялись количественные соотношения кристаллических фаз. Интерпретация дифрактограмм проводилась с использованием данных картотеки ICDD: база порошковых дифрактометрических данных PDF2 (Powder Diffraction File) и дифрактограмм чистых от примесей минералов.

Термический анализ выполнялся на дериватографе Q-1000/D системы F. Paulik, J. Paulik и L. Erdey фирмы «МОМ» (Венгрия) (аналитик к.г.-м.н. И.Б. Саматов). Метод основан на регистрации прибором изменений термохимических и физических параметров вещества, которые могут быть вызваны при его нагревании. Термохимическое состояние пробы описываются кривыми: Т (температурной), DTA (дифференциальной термоаналитической), TG (термогравиметрической) и DTG (дифференциальной термогравиметрической). Последняя из представленных кривых является производной от TG-функции. Съемка осуществлялась в воздушной среде, в диапазоне температур 20-1000 ${ }^{\circ} \mathrm{C}$. Режим нагревания динамический $(d T / d t=10$ град/мин), эталонное вещество - прокаленный $\mathrm{Al}_{2} \mathrm{O}_{3}$, навеска образца - 100 мг, чувствительность весов - 100 мг на шкалу в 200 мм.

\section{Петрография}

Квари-рутил-сидерит-хлоритовые сланцьь, вмещающие медноколчеданные руды, сложены кварцем $(2,0 \%)$, железистым, железомагнезиальным карбонатом, более всего сидеритом (10-20\%), рутилом $(5,0-7,0 \%)$ и железисто-магнезиальным хлоритом.

По химическому составу хлорит, слагающий основную массу породы, приближается к клинохлору, по классификации А.Г. Бетехтина [3], обогащенному $\mathrm{FeO}$ (до 27,08 \%) и отчасти $\mathrm{Al}_{2} \mathrm{O}_{3}(23,62 \%)$. Высокий уровень содержания $\mathrm{Al}_{2} \mathrm{O}_{3}$ при пересчете на нормативный состав дает корунд $(21,50 \%)$, также клинохлор характеризуется высокими содержаниями нормативного оливина $(53,51 \%)$ и гиперстена $(27,10 \%)$, что не исключает его образование по ультраосновным породам. Он почти постоянно содержит примеси $\mathrm{Cr}_{2} \mathrm{O}_{3}(1,49 \%), \mathrm{CuO}(0,70 \%)$ и редко $\mathrm{V}_{2} \mathrm{O}_{5}$ $(0,48 \%)$. 


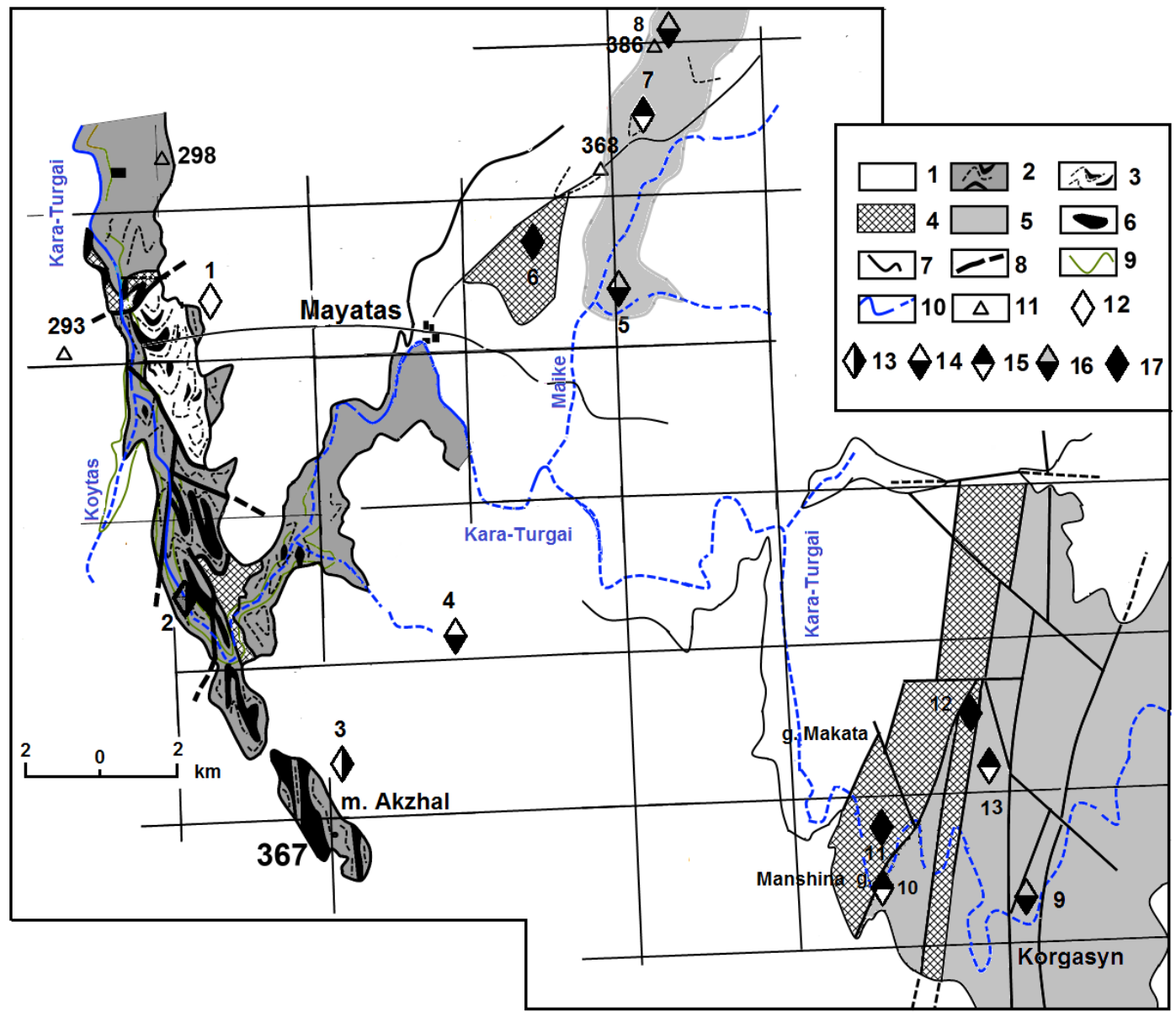

Рис. 1. Схема геологического строения района среднего течения р. Кара-Тургай по И.И. Вишневской и И.Ф. Трусовой [1], С.С. Чудину [2] с изменениями и дополнениями авторов: 1 - кайнозойские отложения; 2, 3 карсакпайская серия $\left(\mathrm{PR}_{2} \mathrm{kr}\right): 2$ - толща метабазальтов, реже андезитов с подчиненными горизонтами мусковитоквариитовых и квариитовых сланщев, 3 - толща пестроцветных туфов квариевых альбитофиров и пепловых полосчатых туфов среднего состава; 4 - аралбайская серия (PR $R_{1}$ ar): мусковито-альбитовые и графитовые сланщы, альбитовые гнейсы и микрогнейсы; 5 - бектурганская серия (PR $\left.R_{l} b t\right)$ : амфиболиты, амфиболитовые, слюдистые сланиы, метасоматиты маятасского комплекса и коры выветривания по ним; 6 - каратургайский долерито-пикритовый комплекс (PR, $k$ ); 7 - геологические границы; 8 - тектонические нарушения; 9 - топографические изолинии; 10 - река Кара-Тургай и ее притоки Койтас и Майке; 11 - тригонометрические высоты; 12-17 - генетические типы месторождений полезных ископаемых; 12 - магматическая группа (ликвачионный класс), сульфидные медно-никелевые с платиноидами и редкоземельными элементами (Dy, Y, Се) руды в пикритах; 13-16 - флюидно-магматический класс, 13 - карбонатитьл квари-карбонатальбитового состава с сульфидами меди и платиноидами, 14 - сульфидные медно-цинк-свинцовые руды с платиноидами и редкоземельными элементами (Y, TREE) в углеродисто-карбонатных сланцах, 15 - медноколчеданные руды с платиноидами и редкоземельными элементами в карбонатитах линейно-трещинного типа, 16 - свинцовые руды с редкоземельными элементами в углеродисто-карбонатных сланиах; 17 - гидротермальная группа (золото). Рудопроявления: 1 - Каратургай, 2 -Северный Акжал, 3 - Восточный Акжал, 4 - Барха, 5 - Заречное, 6-Крестовое-Увальное, 7 - Майке, 8 - Бошке, 9 - Коргасын, 10 - Ажин, 11 - проявление № 76, 12 - проявление № 6, 13 - проявление № 60

Fig. 1. Geological aspects scheme at the middle reaches of Kara-Turgai [1,2] with authors' edits and additions: 1 -Cenozoic sedimentary cover; 2, 3 - Karsakpai series (Mesoproterozoic): 2 - units of metabasalts, occasional andesites with subordinate horizons of muscovite-quartzite and quartzite shales, 3 - units of multicolored tuffs of quartz albitophyres and ash banded tuffs of medium composition, 4 - muscovite-albite and graphite shales, albite gneisses and microgneiss of the Aralbaia Series (PR $\left.R_{l} a r\right) ; 5$ - Bekturgan series (PRIbt): amphibolites, amphibolite, micaceous schists, carbonatites of the Maytas complex and weathering crusts; 6 - Karaturgai dolerites-picritic complex $\left(P R_{3} k\right)$; 7 - geological boundaries; 8 -tectonic disturbances; 9 - topographical isolines; 10 - the river Kara-Turgai and its tributaries Koitas and Mayke; 11 - trigonometric heights; 12-17-genetic types of mineral deposits; 12 - magmatic group (liquation class), sulfide copper-nickel ores with platinum and REE (Dy, Er, Y, Ce) in picrites; 13-16 - fluidmagmatic class; 13 - quartz-carbonate-albite metasomatic composition with copper sulphides and platinoids; 14 sulfide copper-zinc-lead ores with platinoids and REE and $Y$ in carbonaceous-carbonate schists; 15 - copper-pyrite ores in metasomatic of linear-crack type; 16 - lead ores with rare earth elements in carbonaceous schists; 17 - hydrothermal group (gold). Ore deposits: 1 - Karaturgay, 2 - North Akzhal, 3 -Eastern Akzhal, 4 - Barha, 5 - Zarechnoe, 6-Krestovoe-Uvalnoe, 7 - Mayke, 8 - Boshke, 9 - Korgasyn, 10 - № 76, 11 - № 6, 12 - № 60 


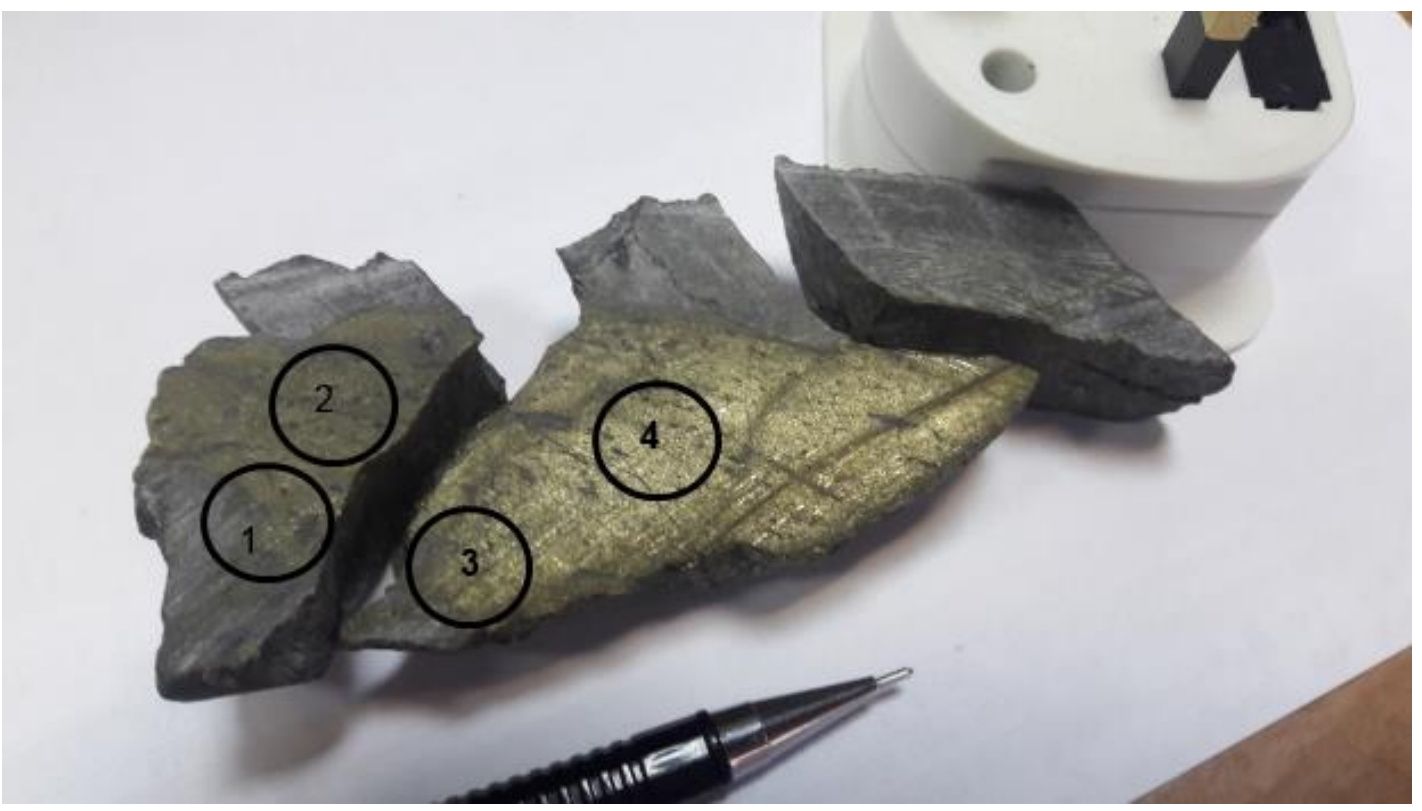

Pис. 2. Кругами указаны места отбора образиов на аншлифы из керна скважины № $n$-10

Fig. 2. Circles show the sampling points for the polished sections from the core of the borehole no. n-10

Рутил образует пластинки, как правило, ориентированные параллельно слоистости, отмечающейся в сланцах. Он содержит примеси $\mathrm{Al}_{2} \mathrm{O}_{3}(3,10 \%), \mathrm{FeO}$ $(3,94 \%)$ и $\mathrm{MgO}(5,20 \%)$.

Хлориты прослоены железистым, железистомагнезиальным карбонатом (сидеритом), в который проникают мелкие чешуйки хлорита, что создает впечатление их сингенетичности. Уровень содержания $\mathrm{FeO}$ не превышает $60 \%$, в составе примесей встречаются такие оксиды, как: $\mathrm{CaO}(2,86$ \%), $\mathrm{CuO}(0,99 \%)$, $\mathrm{MgO}(1,24 \%), \mathrm{MnO}(0,37 \%), \mathrm{SO}_{3}(0,32 \%)$.

Квари выполняет трещины и пустоты, нередко ассоциирует $\mathrm{c}$ сидерит-хлорит-сульфидной массой. Редко в кварце встречается микровключения хромита, содержащие редкоземельные элементы (Y, La, Ce), фосфаты, слагающие прожилки в халькопирите, также содержат элементы цериевой подгруппы. Часто встречаются хорошо ограненные кристаллики циркона и апатита.

Сидерит и хлорит содержат включения или сами заключены в сульфиды, большей частью в халькопирит (рис. 3, А, В), а также присутствует виоларит, пирит, пирротин, сфалерит. В халькопирите встречаются микроскопические зерна сульфидов железа, меди, свинца и рения, виоларит и сфалерит содержат примеси $\mathrm{Er}$ и $\mathrm{Cd}$. Также в халькопирите встречаются включения минералов кобальтин-герсдорфитового ряда, содержащие Pt, Ir, Rh, Ru, Os, образующие микроминералы и фазы, мелонит и вавринит напротив содержат только Pd.

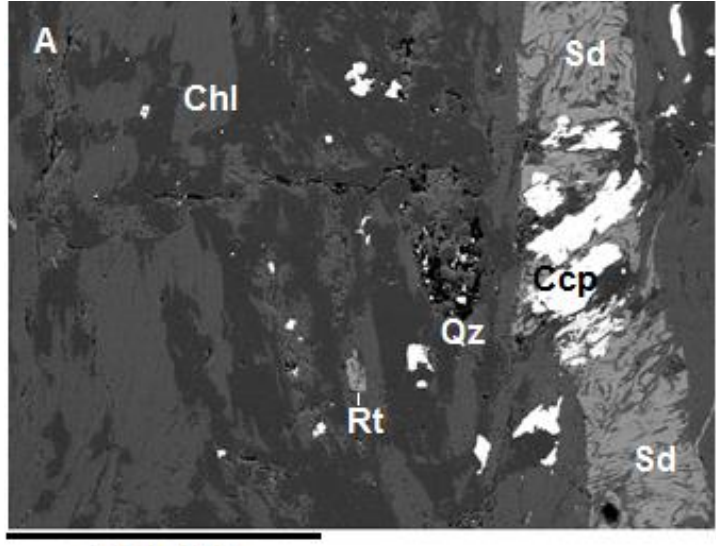

$400 \mu \mathrm{m}$

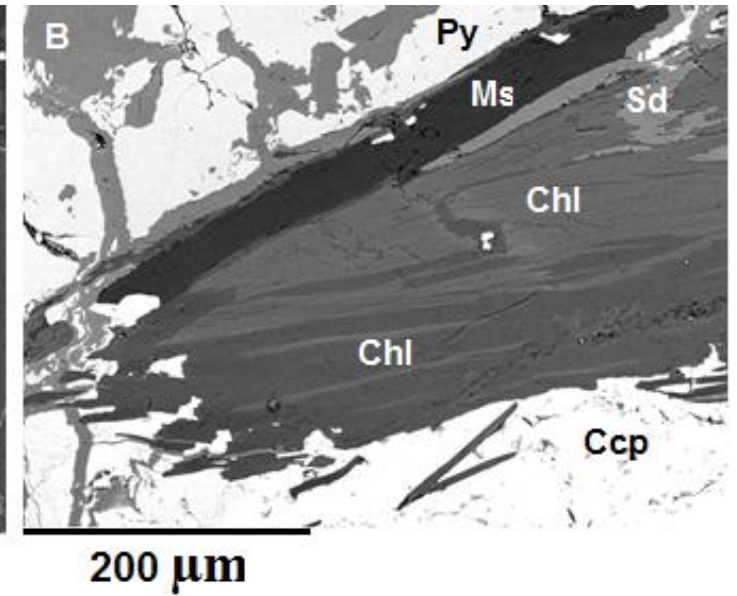

Рис. 3. Изображение в обратно-рассеянных электронах участков анилифа керна скважины № n-10: А) кварирутил-сидерит-хлоритовые сланцы, вмещающие медноколчеданные руды; В) ксенолит сидерит-мусковитхлоритовых сланцев. Хлорит (Chl); квари (Qz); мусковит (Ms); рутил (Rt); сидерит (Sd); халькопирит (Ccp); nupum $(P y)$

Fig. 3. Back-scattered electron image of polished sections made from ore samples containing core of the borehole no. $n$-10: A) quartz-rutile-siderite-chlorite schists containing copper-pyrite ores; B) xenolith siderite-muscovite-chlorite shale. Chlorite (Chl); quartz (Qz); muscovite $(M s)$; rutile Rt); siderite $(S d)$; chalcopyrite $(C c p)$; pyrite $(P y)$ 
По данным полуколичественного рентгенофазового анализа кристаллических фаз в составе сидериткварц-рутил-хлоритовых сланцев содержание альбита $(45,8 \%)$, хлорита $(32,0 \%)$, кварца $(13,0 \%)$, кальцита $(6,2 \%)$, сидерита $(3,1 \%)$. Присутствие карбонатов в составе сланцев установлено и термическим анализом, указывающим на их мантийное происхождение.

По результатам атомно-эмиссионного полуколичественного спектрального анализа сланцы содержат в значимых концентрациях: Y (30 г/T), La (30 г/T), Ce (70 г/T), V (200 г/T), Cr (150 г/T), а также Ba $(0,02 \%)$, $\operatorname{Mn}(0,02 \%)$, As (0,01\%), Pb (<0,002\%), Sb $(<0,002 \%)$, при крайне высоких содержаниях $\mathrm{Cu}(>1,0 \%)$.

Сидерит-мусковит-хлоритовые сланцы слагают линейно вытянутые прослои или ксенолиты, заключённые в рудную массу. Минеральные составы сланцев и их взаимоотношения с рудными минералами показаны на рис. 3.

Хлорит слагает большую часть сланцев и по химическому составу отвечает в целом клинохлору. Более темные его полоски обогащены $\mathrm{MgO}(17,73 \%)$, но обеднены $\mathrm{Al}_{2} \mathrm{O}_{3}(19,64 \%), \mathrm{FeO}(31,50 \%)$ при этом светлые полоски содержат $\mathrm{V}_{2} \mathrm{O}_{5}(0,33 \%), \mathrm{Cr}_{2} \mathrm{O}_{3}(1,34 \%), \mathrm{MnO}$ $(0,51 \%)$. По отношению к хлориту из кварц-рутилсидерит-хлоритовых сланцев клинохлор сидеритмусковит-хлоритовых сланцев несколько обеднен $\mathrm{MgO}$, однако он в целом содержит больше $\mathrm{Cr}_{2} \mathrm{O}_{3}$.

Мусковит по уровню содержания $\mathrm{Cr}_{2} \mathrm{O}_{3}(3,17 \%)$ отвечает фукситу. С фукситом ассоциирует сидерит с примесями $\mathrm{MgO}(0,65 \%), \mathrm{MnO}(0,32 \%)$ и $\mathrm{CaO}(2,20 \%)$

Мусковит и клинохлор характеризуются высокой температурой полного плавления.

За пределами рудной зоны установлены прожилки углеродсодержащих и графит-мусковит-клинохлоральбитовых сланцев, пронизанных тонкими прожилками карбонат железистого алюмосиликата, содержащего до 15 \% LREE.

По данным Р.А. Нсанова [4] мусковитсодержащие сланцы характеризуются ярко выраженной иттриеносностью.

В составе кор выветривания по кварц-рутил-сидеритхлоритовым, сидерит-мусковит-хлоритовым сланцам, наряду с апатитом, сфеном, ильменитом, гранатом, цирконом, встречаются желваки черчита [4]. Неодимовая разновидность черчита является основным источником иттрия, европия и тяжелых лантаноидов. Черчит, по мнению [4], является продуктом изменения микровключений реликтовых относительно устойчивых REEминералов типа паризита, ксенотима, монацита.

\section{Петрологическая специализация}

\section{рудовмещающих толщ}

Нормативный минеральный состав клинохлора кварц-рутил-сидерит-хлоритовых и сидерит-мусковитхлоритовых сланцев дает нам право предположить, что данные породы есть продукт метаморфизма щелочных ультраосновных пород, вероятнее всего эссексит-пикритов. На щелочную природу исходного материнского материала указывает и присутствие постмагматических продуктов (фосфатов), содержащих элементы цериевой подгруппы. Этот вывод согласуется и с присутствием в составе коры выветри- вания, вскрытой скважиной № 7 в интервале глубин от 19,2 до 24,0 м в профиле рудной зоны монтмориллонита, который образуется, как правило, по основным и ультраосновным горным породам [3].

Ассоциация карбонатов, включая сидерит, апатита, титанита, альбита, кварца, граната (пиропальмандинового ряда), хромсодержащего мусковита и обогащенного хромом клинохлора и их пространственная связь с графит-кварц-хлоритовыми сланцами позволяет рассматривать сланцы составной частью силицит-карбонат-углеродистого комплекса, отражающего состав ростового расплава мантийного происхождения. Интенсивно рассланцованный материал углерода, клинохлора и карбоната обогащен сульфидами, которые, как правило, встречаются на плоскостях рассланцевания. Углеродистый материал проникает в клинохлор-карбонат-кварцевый материал. Часто можно наблюдать, что этот материал пронизан тонкими прожилками сульфидов.

По мнению Ю.А. Литвина [5, 6], силициткарбонат-углеродистый расплав является высокоэффективной алмазообразующей средой, что установлено экспериментально. Присутствие алмаза в составе графитов карбонатитов описываемого комплекса было еще ранее доказано В.А. Чевердиным и Ю.А. Смеловым (1988). Этот вывод вполне согласуется с присутствием фуллерена и алмаза в графитмусковит-полевошпат-кварцевых сланцах Керегешинского рудного поля, что обнажается югозападней г. Аркалык [7], которые находятся в переслаивании с метаморфизованными вулканитами базальт-риолитовой карасулейменской толщи. По данным С.С. Чудина [7], содержание графита в этих сланцах достигает $4,12 \%$, большая часть которого слагает тонкие чешуйки мощностью менее 1,0 мм с температурой выгорания $900{ }^{\circ} \mathrm{C}$. В углеродсодержащих сланцах также установлены незначительные концентрации платины и палладия, что указывает на неорганическое происхождение углерода.

Карбонатиты довольно широко представлены в районе поселка Коргасын (Кургасын) [8], что лежит в излучине реки Кара-Тургай (рис. 1). Здесь в составе хлоритоальбитовой толщи встречаются карбонатизированные мусковито-альбитовые и карбонатизированные графитсодержащие мусковито-хлорито-кварцевые сланцы, аналогичные тем, что были описаны на Керегешинском рудном поле [7] и нами в пределах проявления Майке [9]. Важно отметить, что графит-мусковит-кварцевые и графит-мусковит-хлорит-полевошпат-кварцевые сланцы этих комплексов содержат колчеданнополиметаллические оруденения. В районе Керегешин сульфиды, в составе графитсодержащих пород, достигают $15 \%$ (пирротин, пентландит, пирит, халькопирит, сфалерит, галенит, марказит, кубанит, арсенопирит, борнит), присутствие полисульфидной ассоциации, аналогичной по составу таковой карбонатитам Майке, что не исключает обнаружение в ней платиноидов.

По данным И.И. Вишневской и И.Ф Трусовой [1], акцессорные минералы графитсодержащих пород представлены апатитом, титанитом, цирконом, турмалином, гранатом (3\%) и графитом (до $12 \%)$. Хи- 
мический состав граната: альмандин $\left(\mathrm{Fe}_{3} \mathrm{Al}_{2}\left[\mathrm{SiO}_{4}\right]_{3}\right)-$ 50 мол. \%, гроссуляр $\left(\mathrm{Ca}_{3} \mathrm{Al}_{2}\left[\mathrm{SiO}_{4}\right]_{3}\right)$ - 32 мол. \%, пироп $\left(\mathrm{Mg}_{3} \mathrm{Al}_{2}\left[\mathrm{SiO}_{4}\right]_{3}\right)-7$ мол. \%. Редко циркон, апатит и титанит образуют округлые зерна размером до 0,02 мм.

Как отмечает Г.П. Зарайский [10], парагенезис турмалина с мусковитом указывает на хлоридноборнокислый состав растворов, под воздействием которых происходят гидротермальные изменения пород.

Выходы метасоматитов в районе поселка Коргасын сопровождаются литогеохимическими ореолами $\mathrm{Y}, \mathrm{Yb}$, $\mathrm{La}$ и $\mathrm{Au}$, также $\mathrm{Pb}, \mathrm{Ag}, \mathrm{W}, \mathrm{Y}, \mathrm{Li}$, что дает основание провести параллель с карбонатами Маятасского рудного района. К ореолам $\mathrm{Pb}, \mathrm{Ag}, \mathrm{W}, \mathrm{Y}, \mathrm{Li}$ приурочено месторождение свинца с пиритом и халькопиритом. По данным Л.А. Мирошниченко и А.В. Попова [11], галенитовые руды содержат редкоземельную минерализацию в виде мелких включений фторкарбонатов и фосфатов. Состав фторкарбонатов (в \%): $\mathrm{La}-22,5$; $\mathrm{Ce}-$ 36,$1 ; \mathrm{Pr}-6,2, \mathrm{Nd}-20,0 ; \mathrm{Sm}-3,0 ; \mathrm{Gd}-5,7 ; \mathrm{Te}-0,6$ и $\mathrm{Y}-1,5$; фосфатов: $\mathrm{La}-22,7 ; \mathrm{Ce}-42,3 ; \mathrm{Pr}-6,0 ; \mathrm{Nd}-$ 19,$0 ; \mathrm{Sm}-4,4 ; \mathrm{Eu}-0,4 ; \mathrm{Gd}-5,2$. Его аналогом является месторождение Заречное, полиметаллические руды которого наряду с галенитом содержат сфалерит, смитсонит, а также $\mathrm{Au}, \mathrm{Ag}, \mathrm{Pt}, \mathrm{Pd}$ и REE (Y, Yb).

В существующих объемных моделях вертикальной зональности оруденения карбонатитовых массивов плутонического типа, как правило, выше гематитовых и баритстронцианитовых месторождений располагаются ториеворедкоземельные с сульфидами меди, свинца и цинка проявления, которые приурочены к анкерито-доломитовым жилам [12]. Для описываемого нами типа характерно присутствие графит-мусковит-клинохлор-углеродистых и графит-мусковит- клинохлор-карбонат-кварцевых жил, содержащих медноколчеданные руды, обогащенные платиноидами и редкоземельными минералами.

\section{Минералогия}

В составе прожилка мощностью до 35 см, вскрытого скважиной № п-10 на глубине 100 м, были установлены: халькопирит (>95 \%), виоларит, пирит, сфалерит, пирротин (в порядке убывания), нерудные минералы представлены сидеритом и гематитом.

Микровключения в халькопирите представлены самородным серебром (78,18 \% Ag), теллуридом серебра $\left(\mathrm{Ag}_{2} \mathrm{Te}\right)$, акантитом $\left(\mathrm{Ag}_{2} \mathrm{~S}\right)$, кобальтином (CoAsS), герсдорфитом (NiAsS), минералами кобальтин-герсдорфитового ряда с $\mathrm{Pt}, \mathrm{Ir}, \mathrm{Rh}, \mathrm{Ru}, \mathrm{Os}$, вавринитом $\left(\mathrm{Ni}_{2} \mathrm{SbTe}_{2}+\mathrm{Pd}+\mathrm{Ag}\right)$, сперрилитом $\left(\mathrm{PtAs}_{2}\right)$, тестибиопалладитом (Pd( $\mathrm{Sb}, \mathrm{Bi}) \mathrm{Te})$, мелонитом $\left(\mathrm{NiTe}_{2}\right)$, галенитом (PbS), ульманнитом (NiSbS), фосфатом, фторфосфатом с REE и алюмосиликатом с LREE, также обнаружены фазы (Pb, Ag)Tе и PbTe. Особую группу микровключений образуют многочисленные минеральные фазы сульфидов Re, Mo, $\mathrm{Cu}, \mathrm{Fe}, \mathrm{Pb} \mathrm{Bi}$.

\section{Основные рудные минералы}

Халькопирит $\left(\mathrm{CuFeS}_{2}\right)$ слагает основную массу руды (более 95 \%), с ним ассоциируют все нижеописанные минералы. В халькопирите примеси платиноидов и REE не обнаружено. Учитывая средний химический состав $(35,20 \% \mathrm{~S}, 30,32 \% \mathrm{Fe}, 34,52 \% \mathrm{Cu})$ халькопири- та, его кристаллохимическая формула имеет вид $\mathrm{Cu}_{1,0} \mathrm{Fe}_{1,0} \mathrm{~S}_{2,02}$ при крайне малом избытке серы.

Виоларит $\left(\mathrm{FeNi}_{2} \mathrm{~S}_{4}\right)$ представляет собой полную псевдоморфозу по пентландиту, в которой сохраняется типичная для пентландита спайность. Зерна виоларита имеют неправильную форму, их размер достигает 500 мкм. В качестве примеси в виоларите присутствует Сo $(<1,25 \%)$, реже отмечаются беспримесные формы. Крайне редко он содержит микровключения теллурида серебра. Средний химический состав виоларита следующий: 42,54 \% S, 21,32 \% Fe, 34,03 \% Ni. Его кристаллохимическая формула с учетом среднего химического состава имеет вид $\left(\mathrm{Fe}_{1,19} \mathrm{Ni}_{1,81}\right)_{\sum 3,0} \mathrm{~S}_{4,14}$. В целом в виоларите отмечается избыток серы и железа. Встречено единичное зерно виоларита с сетчатой структурой распада.

Пентландит $\left(\mathrm{Fe}_{4} \mathrm{Ni}_{4}(\mathrm{Fe}, \mathrm{Co}, \mathrm{Ni}) \mathrm{S}_{8}\right.$ встречается крайне редко. Он сильно обогащен серой.

Пирротин $\left(\mathrm{Fe}_{1.0} \mathrm{~S}_{1.14}\right)$ встречается крайне редко, и он характеризуется избыточным содержанием серы.

Пирит $\left(\mathrm{FeS}_{2}\right)$ слагает ксеноморфные зерна размером до 200 мкм, погруженные в халькопирит. Нередко можно наблюдать, как пирит по трещинам проникает в халькопирит. В качестве примеси почти постоянно присутствует $\mathrm{Ni}(0,41-3,71 \%)$ и значительно реже - $\mathrm{Cu}(0,63-0,75 \%)$. Высокие концентрации $\mathrm{Ni}$ (2,67-3,71 \%) характерны для пирита, ассоциирующего с виоларитом. Также в этом пирите отмечается незначительный недостаток серы $\left(\mathrm{Fe}_{0,97} \mathrm{Ni}_{0,06} \mathrm{~S}_{1,97}\right)$. Стехиометрическая формула пирита имеет вид $\mathrm{Fe}_{0,99} \mathrm{Ni}_{0,01} \mathrm{~S}_{2,00}$, развивающийся по трещинам и слагающий отдельные зерна в халькопирите.

Cфалерит $((\mathrm{Zn}, \mathrm{Fe}) \mathrm{S})$ встречается крайне редко и часто совместно с микровключениями кобальтина (рис. 4). Он, как правило, содержит примесь $\mathrm{Cd}$ $(0,66-0,76 \%)$ и $\mathrm{Cu}(0,80-1,30 \%)$, но недосыщен $\mathrm{Fe}$ (6,77-7,03\%). Исходя из среднего химического состава $(32,28 \% \mathrm{~S}, 6,89 \% \mathrm{Fe}, 1,10 \% \mathrm{Cu}, 0,72 \% \mathrm{Cd}$, $56,70 \% \mathrm{Zn)}$ сфалерита, его кристаллохимическую формулу можно представить как $\mathrm{Zn}_{0,86} \mathrm{Fe}_{0,12} \mathrm{Cu}_{0,02} \mathrm{~S}_{1,03}$ при крайне малом избытке серы. Сфалерит, встречающийся в ассоциации с акантитом, не содержит $\mathrm{Cd}$, но обогащен $\mathrm{Fe}(8,45 \%), \mathrm{Cu}(2,46 \%)$ и не испытывает избытка серы $\left(\mathrm{Zn}_{0,79} \mathrm{Fe}_{0,14} \mathrm{Cu}_{0,04} \mathrm{~S}_{1,00}\right)$.

\section{Микровключения}

Ряд кобальтин-герсдорфит. Ni-Co-сульфоарсениды в основном представлены промежуточными членами ряда кобальтин-герсдорфит - никелистым кобальтином и реже кобальтином, феррокобальтином и герсдорфитом (рис. 4). Они образуют минералы двух типов, зональные и незональные кристаллы, которые слагают гирлянды кристаллов и одиночные хорошо ограненные прямоугольные, ромбические, пятигранные и шестигранные пластинки. Максимальный размер одиночных пластинок не превышает 30 мкм, как правило, их величина составляет от 5 до 15 мкм. Нередко можно наблюдать соседство кобальтина со сфалеритом (рис. 4, В). Также минерал часто обрастает мелонитом, тестибиопалладитом, теллуридом серебра и магнетитом. Мышьяк значительно преобладает над серой независимо от уровня содержания Сo и $\mathrm{Ni}$. 


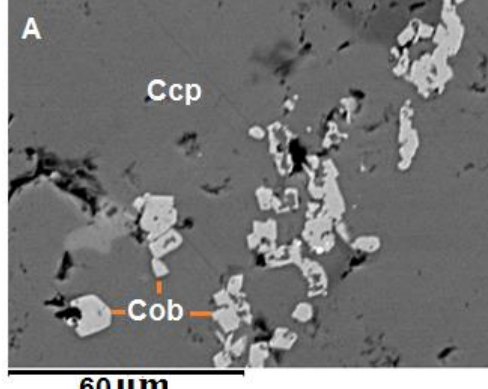

$60 \mu \mathrm{m}$

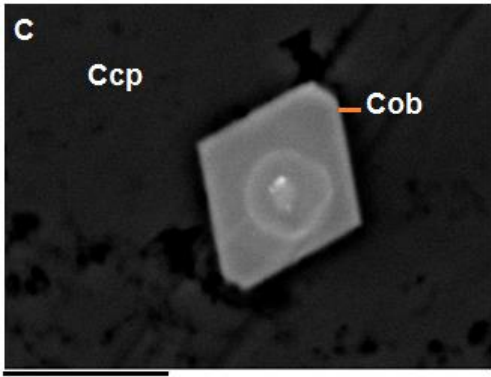

$10 \mu \mathrm{m}$

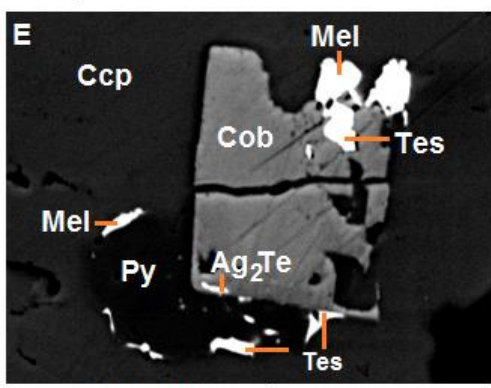

$40 \mu \mathrm{m}$

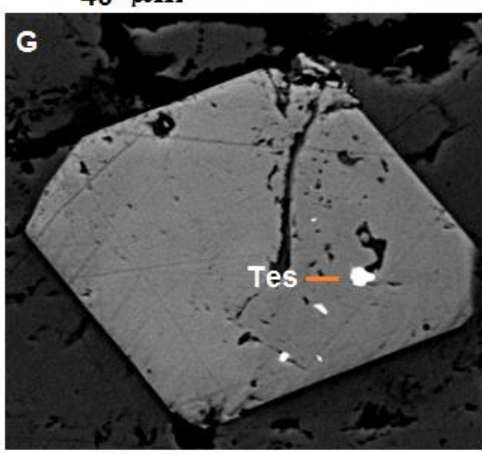

$50 \mu \mathrm{m}$

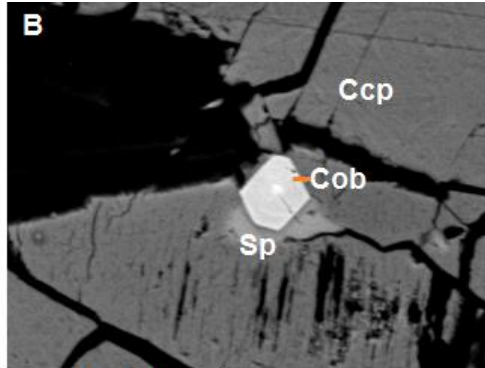

$40 \mu \mathrm{m}$

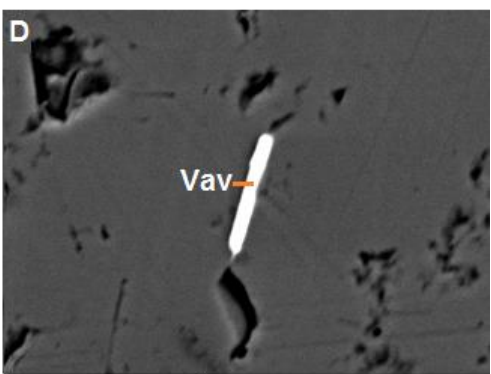

$30 \mu \mathrm{m}$
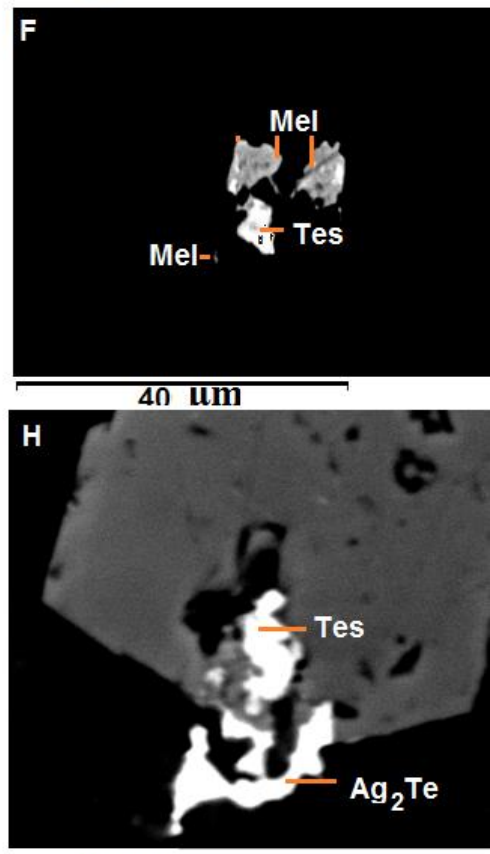

$10 \mu \mathrm{m}$

Pис. 4. Изображение в обратно-рассеянных электронах участков аншлифа рудных минералов керна скважины № $n$ 10: А) характер взаимоотношения халькопирита и кобальтина, образующего сплошные массы, зерна неправильной, реже идеально ограненные кристалль; $B, C)$ идеальные кристалль зонального никелистого кобальтина: B) яркое зерно в центре - Pt; C) яркое зерно в иентре и кольчо содержат $R u, R h, O s, I r, P t$; D) yдлиненная пластинка вавринита (Ni $\left.\mathrm{SbTe}_{2}\right)$; E) характер прорастания халькопирита минералом кобальтингерсдорфитового ряда и его мелонитом, тестибиопалладитом и $\mathrm{Ag}_{2} \mathrm{Te}$; F) пример отличия минералов по среднему атомному номеру фазы $(Z$ ср.). Чем больше $Z$ ср., т. е. чем больше тяжёльх элементов, тем светлее эта фаза на изображении (мелонит $Z$ cp.=44, тестибиопалладит $Z c p .=55$ ); $G$ ) никелистый кобальтин $c$ микровключением тестибиопалладита; H) никелистый кобальтин с микровключениями тестибиопалладита и теллурида серебра

Fig. 4. Back-scattered electron image of polished sections made from ore samples containing core of the borehole no. $n$-10: A) nature of the germination of chalcopyrite by cobaltin, forming continuous masses, irregular grains, rarely ideally faceted shapes; $B, C$ ) ideal crystals of polished nickel-plated cobaltite; B) bright grain in the center is Pt; C) bright grain in the center and the ring contain $\mathrm{Ru}, \mathrm{Rh}, \mathrm{Os}, \mathrm{Ir}, \mathrm{Pt} ; \mathrm{D})$ elongated plate of wavrinite $\left.\left(\mathrm{Ni}_{2} \mathrm{SbTe}_{2}\right) ; \mathrm{E}\right)$ nature of the germination of chalcopyrite by the mineral of the cobaltin-gersdorfite series and its melonite, testibiopalladite and $\left.\mathrm{Ag}_{2} \mathrm{Te} ; \mathrm{F}\right)$ example of the difference in minerals by the average atomic phase number ( $\mathrm{Z}$ med.). The larger $\mathrm{Z}$ med., more heavy elements, the lighter this phase in the image (melonite $Z$ med. $=44$, testibiopalladium $Z$ med.=55); $G)$ nickel-plated cobaltite with microincorporation of testibiopalladite; $H)$ nickel-plated cobaltite with microinclusions of testibiopalladite and silver telluride 
Герсдорфит (NiAsS) по составу приближается к стехиометрической формуле $\mathrm{Ni}_{1,02} \mathrm{As}_{0,99} \mathrm{~S}_{0,99}$. Из примесей в составе герсдорфита присутствует $\mathrm{Sb}(1,60 \%)$ $\mathrm{Fe}(0,2 \%)$ и $\mathrm{Co}(0,1 \%)$ (табл. 1$)$.

Кобальтин (CoAsS) встречается чаще, чем герсдорфит. Он слагает грозди и одиночные шестигранные, реже ромбические кристаллы (рис. 4 , А) и, как правило, кобальтин незональный (рис. 5). По отношению к стандартному кобальтину [3] он обогащен $\mathrm{Ni}(<9,20 \%)$, и, как правило, присутствует примесь $\mathrm{Fe}$ $(4,83-5,97 \%)$ и $\mathrm{Cu}(1,08-2,93 \%)$.

Средний химический состав кобальтина, рассчитанный по пяти анализам, следующий: $22,18 \% \mathrm{Co}$, $7,56 \% \mathrm{Ni}, 5,69 \% \mathrm{Fe}, 20,18 \%$ S, 42,33 \% As. Его теоретическая формула с учетом среднего химического состава имеет вид: $\left(\mathrm{Co}_{0,62} \mathrm{Ni}_{0,11} \mathrm{Fe}_{0,17} \mathrm{Cu}_{0,04}\right)_{1,04} \mathrm{As}_{0,93} \mathrm{~S}_{1,03}$. В составе кобальтина постоянно отмечается недостаток мышьяка.

Никелистый кобальтин (NiCoAsS) представлен зональными и незональными кристаллами, которые существенно различаются по цвету. Зональные кристаллы имеют светлый и матовый оттенок, что обусловлено присутствием платиноидов. Незональныее кристалль никелистого кобальтина имеют серую окраску, отдельные его кристаллы достигают 90 мкм в поперечнике, они хорошо огранены и представлены шестигранниками и прямоугольниками (рис. 4, 5), крайне редко встречаются его скелетные кристаллы (рис. 5). Он содержит микровключения тестибиопалладита, мелонита и теллурида серебра, которые вместе с никелистым кобальтином заключены в халькопирит. Отдельные микровключения незонального никелистого кобальтина обогащены эрбием $(<7,32 \%)$ и часто содержат примесь меди $(<7,72 \%)$.

Несмотря на слабую разницу химического состава незонального никелистого кобальтина, все же были рассчитаны две формулы с учетом их различия по содержанию мышьяка и серы. Низкосернистый никелистый кобальтин по химическому составу приближается к стехиометрической формуле $\left(\mathrm{Ni}_{0,53} \mathrm{Co}_{0,24} \mathrm{Fe}_{0,21} \mathrm{Cu}_{0,03}\right)_{\Sigma 1,01} \mathrm{As}_{1,00} \mathrm{~S}_{0,99}$, тогда как в обогащенных серой минералах отчетливо проявлен недостаток мышьяка, что отчетливо видно по формуле $\left(\mathrm{Ni}_{0,44} \mathrm{Co}_{0,33} \mathrm{Fe}_{0,22} \mathrm{Cu}_{0,04}\right)_{\sum 1,03} \mathrm{As}_{0,94} \mathrm{~S}_{1,03}$. Недостаток мышьяка отмечен и в незональном кобальтине.

Кристаллохимическая формула соответствует номеру анализа:

1. $\mathrm{Ni}_{1,02} \mathrm{As}_{0,99} \mathrm{~S}_{0,99}$;

2. $\left(\mathrm{Ni}_{0,38} \mathrm{Co}_{0,23} \mathrm{Fe}_{0,22} \mathrm{Cu}_{0,08} \mathrm{Er}_{0,08}\right)_{\Sigma 1,00} \mathrm{As}_{1,01} \mathrm{~S}_{0,99}$

3. $\left(\mathrm{Ni}_{0,55} \mathrm{Co}_{0,24} \mathrm{Fe}_{0,20} \mathrm{Cu}_{0,02} \mathrm{Er}_{0,01}\right)_{\Sigma 1,02} \mathrm{As}_{0,99} \mathrm{~S}_{0,99}$;

4. $\left(\mathrm{Ni}_{0,54} \mathrm{Co}_{0,22} \mathrm{Fe}_{0,20} \mathrm{Cu}_{0,03} \mathrm{Er}_{0,01}\right)_{\Sigma 1,00} \mathrm{As}_{1,1} \mathrm{~S}_{0,99}$.

Таблица 1. Результаты микрозондовых анализов (мас. \%) незональных минералов кобальтин-герсдорфитового ряда Table 1. Results of microprobe analyzes (wt. \%) of non-polished minerals of the cobaltin-gersdorffite series

\begin{tabular}{|c|c|c|c|c|c|c|c|c|c|}
\hline № ח/П & Минерал/Mineral & $\mathrm{S}$ & $\mathrm{Fe}$ & $\mathrm{Cu}$ & $\mathrm{Co}$ & $\mathrm{Ni}$ & As & $\mathrm{Sb}$ & Er \\
\hline 1 & Герсдорфит/Gersdorffite & 19,0 & 0,2 & $\mathrm{H}$ & 0,1 & 35,70 & 44,30 & 1,60 & $\mathrm{H}$ \\
\hline 2 & \multirow{3}{*}{$\begin{array}{l}\text { Ni-кобальтин } \\
\text { Ni- cobaltite }\end{array}$} & 17,75 & 7,17 & 2,73 & 7,64 & 12,46 & 42,25 & $\mathrm{H}$ & 7,32 \\
\hline 3 & & 18,89 & 6,60 & 0,71 & 8,57 & 19,12 & 44,49 & $\mathrm{H}$ & 1,40 \\
\hline 4 & & 18,67 & 6,59 & 1,01 & 7,75 & 18,68 & 44,63 & $\mathrm{H}$ & 1,50 \\
\hline
\end{tabular}

Примечание: н-элемент не определен.

Note: $\boldsymbol{H}$ - not determined.
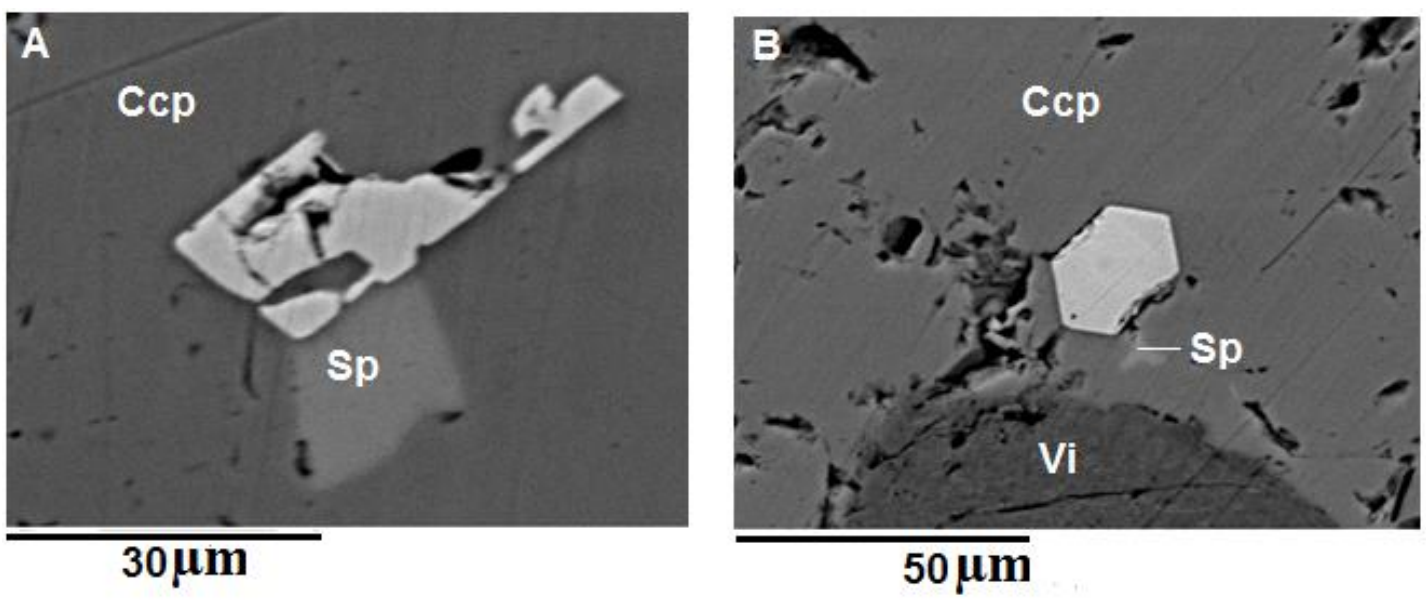

Pис. 5. Изображение в обратно-рассеянных электронах участков аншлифа незонального никелистого кобальтина

Fig. 5. Back-scattered electron image of polished sections made from ore samples containing non-polished nickel-plated cobaltite

Форма, размер и характер строения зональных кристаллов никелистого кобальтина отображены на рис. 6. Характерной особенностью строения кристаллов является присутствие, как правило, ярко белого ядра, представленного платиноидами, в центре мине- рала, от которого отходит кольцо белого или матового цвета (рис. 4, В, С), также встречаются зерна и по периферии кристалла. Нередко эти кристаллы раздроблены. Встречаются кристаллы, в которых центральное ядро отсутствует и наблюдается только 
светлое кольцо или широкий ободок матового или белого цвета. Контрастность белого или матового цвета отражает уровень содержания платиноидов (рис. 6). Максимальное содержание платиноидов в одном из кристаллов зонального никелистого кобальтина составило 17,40 \%, где Ir 13,88; Pt 2,34; Os 1,18. В зональных минералах никелистого кобальтина легкие $(\mathrm{Ru}, \mathrm{Rh})$ и тяжелые $(\mathrm{Pt}, \mathrm{Ir}, \mathrm{Os})$ платиновые метал- лы находятся вместе (табл. 2). Платиноиды (Pt, Ir, Ru, $\mathrm{Rh}, \mathrm{Os})$ образуют микровключения в никелистом кобальтине. Поликомпонентные твердые растворы системы Pt-Ir-Os-Ru-Rh образуют следующие разновидности: (Pt, Ir), (Ir, Pt), (Pt, Ir, Ru, Os, Rh), (Ir, Pt, Os), (Ir, Pt, Rh), (Ru, Os), (Ir, Pt, Rh, Ru), (Pt, Os), соединения перечислены в порядке убывания.

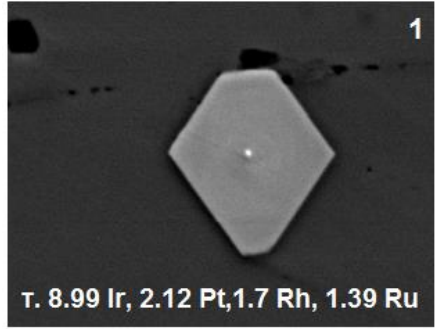

$20 \mu \mathrm{m}$

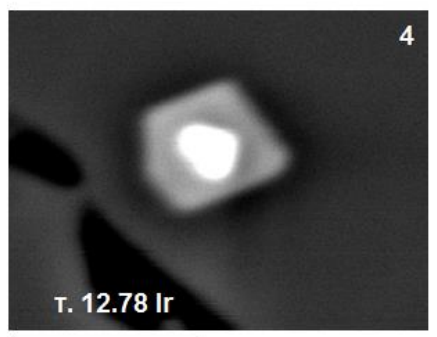

$5 \mu \mathrm{m}$

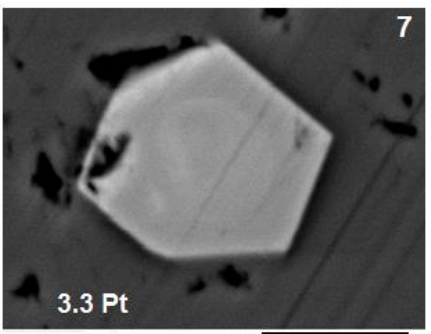

$10 \mu \mathrm{m}$

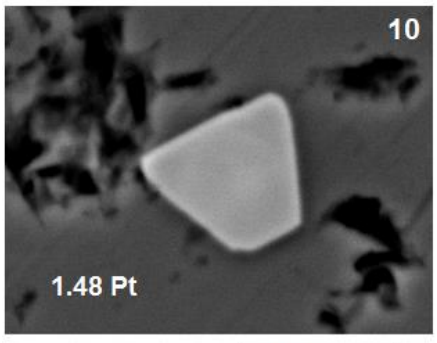

$10 \mu \mathrm{m}$

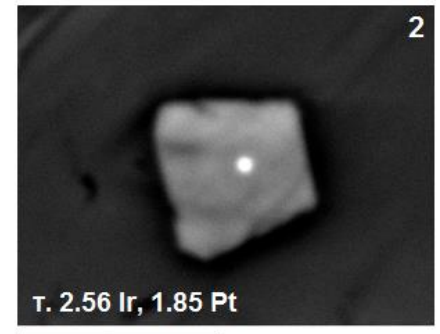

$10 \mu \mathrm{m}$

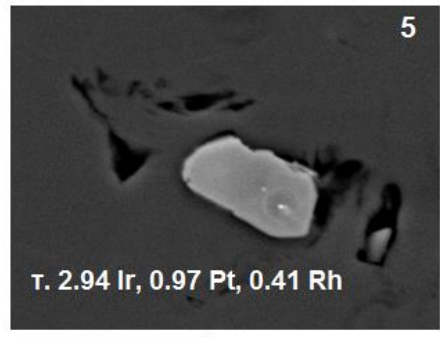

$20 \mu \mathrm{m}$

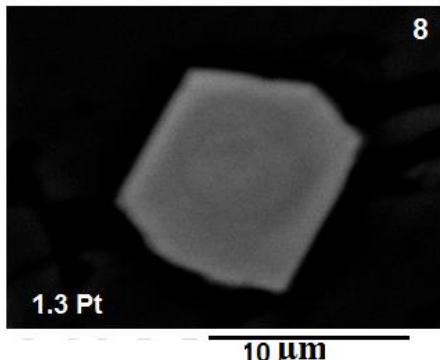

$10 \mu \mathrm{m}$

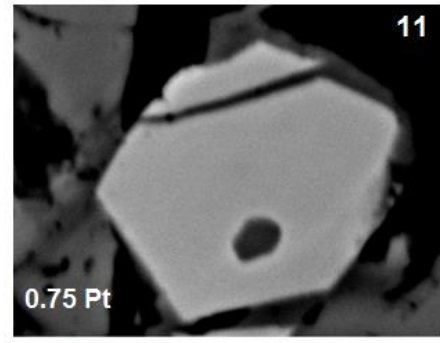

$10 \mu \mathrm{m}$

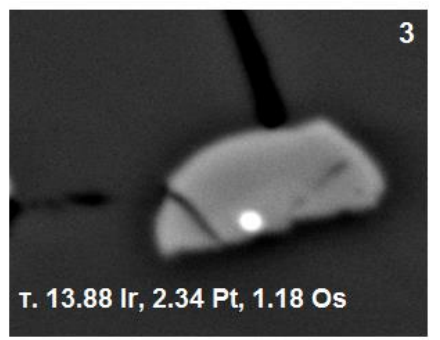

$8 \mu \mathrm{m}$

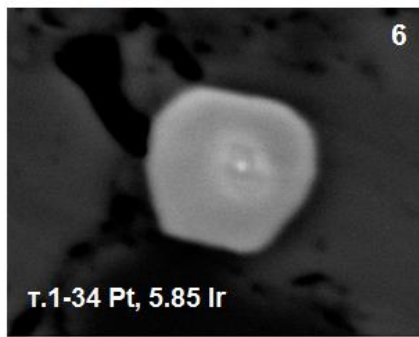

$9 \mu \mathrm{m}$
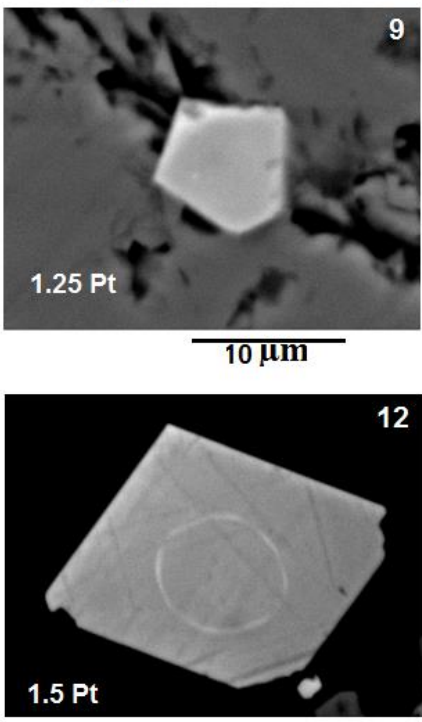

$20 \mu \mathrm{m}$

Рис. 6. Изображение в обратно-рассеянных электронах участков аншлифа зональных минералов никелистого кобальтина с идиоморфными (1-3) ядрами, ксеноморфными выделениями (7-12) и смешанными (4-6) типами платиноидов

Fig. 6. Back-scattered electron image of polished sections made from ore samples containing polished nickel-plated cobaltite with idiomorphic (1-3) nuclei, xenomorphic precipitates (7-12) and mixed (4-6) types of platinoids

В тех случаях, когда в составе никелистого кобальтина присутствует платина и иридий, формула имеет стехиометрический вид

$\left(\mathrm{Ni}_{0,41} \mathrm{Co}_{0,30} \mathrm{Fe}_{0,26} \mathrm{Cu}_{0,03}\right)_{1,00}\left(\mathrm{As}_{0,93} \mathrm{Ir}_{0,05} \mathrm{Pt}_{0,02}\right)_{1,00} \mathrm{~S}_{1,00}$. Если платиноиды отсутствуют, то в формуле

$$
\left(\mathrm{Ni}_{0,47} \mathrm{Co}_{0,29} \mathrm{Fe}_{0,23} \mathrm{Cu}_{0,03}\right)_{1,001} \mathrm{As}_{0,97} \mathrm{~S}_{1,02}
$$

выявляется недостаток мышьяка, что также характерно для незональных кристаллов никелистого кобальтина.

Кристаллохимическая формула соответствует номеру анализа:

$$
\text { 1. }\left(\mathrm{Ni}_{0,50} \mathrm{Co}_{0,23} \mathrm{Fe}_{0,22} \mathrm{Cu}_{0,04}\right)_{\Sigma 0,99}
$$

$\left(\mathrm{As}_{0,96} \mathrm{Ir}_{0,01} \mathrm{Pt}_{0,01} \mathrm{Ru}_{0,02} \mathrm{Os}_{0,01} \mathrm{Rh}_{0,01}\right)_{\sum 1,02} \mathrm{~S}_{0,99}$; 


$$
\begin{aligned}
& \text { 2. }\left(\mathrm{Ni}_{0,50} \mathrm{Co}_{0,22} \mathrm{Fe}_{0,21} \mathrm{Cu}_{0,06}\right)_{\sum 0,99} \\
& \left(\mathrm{As}_{0,96} \mathrm{Ru}_{0,03} \mathrm{Pt}_{0,02} \mathrm{Os}_{0,01}\right)_{\Sigma 1,03} \mathrm{~S}_{0,98}
\end{aligned}
$$

\section{3. $\left(\mathrm{Ni}_{0,37} \mathrm{Co}_{0,24} \mathrm{Fe}_{0,21} \mathrm{Cu}_{0,08}\right)_{\Sigma 0,90}$}

$\left(\mathrm{As}_{0,89} \mathrm{Ir}_{0,06} \mathrm{Rh}_{0,02} \mathrm{Ru}_{0,03} \mathrm{Pt}_{0,02}\right)_{\Sigma 1,02} \mathrm{~S}_{1,07}$

Таблица 2. Результаты микрозондовых анализов (мас. \%) зонального никелистого кобальтина

\begin{tabular}{|c|c|c|c|c|c|c|c|c|c|c|c|c|}
\hline № ח/п & $\begin{array}{c}\text { Минерал } \\
\text { Mineral }\end{array}$ & S & $\mathrm{Fe}$ & $\mathrm{Cu}$ & Co & $\mathrm{Ni}$ & As & $\mathrm{Pt}$ & Ir & $\mathrm{Rh}$ & $\mathrm{Ru}$ & Os \\
\hline 1 & \multirow{3}{*}{$\begin{array}{l}\text { Ni-кобальтин } \\
\text { Ni- cobaltite }\end{array}$} & 18,39 & 6,99 & 1,64 & 7,95 & 16,92 & 41,66 & 1,24 & 1,03 & 0,30 & 1,11 & 0,69 \\
\hline 2 & & 18,46 & 6,95 & 2,14 & 7,65 & 17,07 & 41,96 & 1,98 & 0,78 & 0,35 & 1,94 & 0,91 \\
\hline 3 & & 19,69 & 6,81 & 2,81 & 8,30 & 12,34 & 38,24 & 2,48 & 6,37 & 1,09 & 1,87 & $\mathrm{H}$ \\
\hline
\end{tabular}

Table 2. Results of microprobe analyzes (wt. \%) of polished nickel-plated cobaltite

Встречен один корродированный кристалл ульманнита $(\mathrm{NiSbS})$ в сростках с пиритом и теллуридом серебра (рис. 7). Ульманнит имеет широкий спектр элементов-примесей: $\mathrm{Ag}, \mathrm{Te}, \mathrm{Pd}, \mathrm{Bi}$ (табл. 3), что ха- рактерно для минералов гидротермальных месторождений серебряно-кобальтово-никелевых и кобальтово-никелевых руд.

Таблица 3. Результаты микрозондового анализа (мас. \%) ульманнита

Table 3. Results of microprobe analysis (wt. \%) of ullmannite

\begin{tabular}{|c|c|c|c|c|c|c|c|c|c|c|}
\hline Минерал/Mineral & $\mathrm{S}$ & $\mathrm{Fe}$ & $\mathrm{Sb}$ & $\mathrm{Co}$ & $\mathrm{Ni}$ & $\mathrm{As}$ & $\mathrm{Bi}$ & $\mathrm{Ag}$ & $\mathrm{Te}$ & $\mathrm{Pd}$ \\
\hline Ульманнит/Ullmannite & 10,88 & 1,77 & 41,28 & 0,25 & 18,79 & 1,23 & 8,07 & 7,51 & 7,26 & 2,96 \\
\hline
\end{tabular}

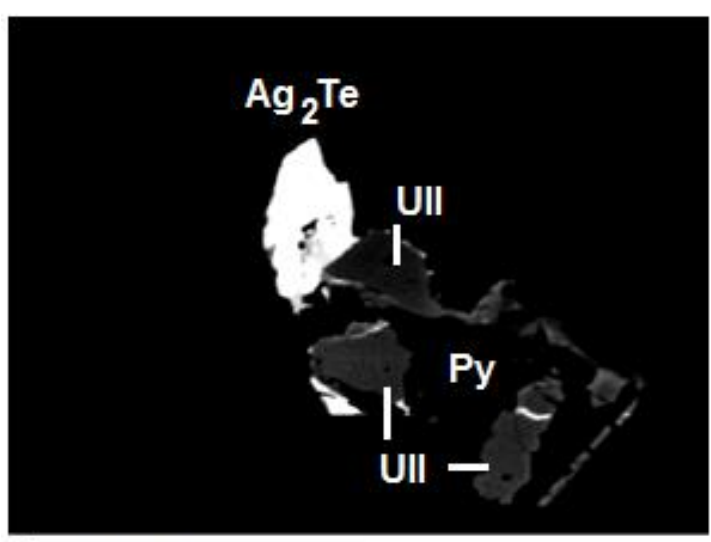

$14 \mu \mathrm{m}$

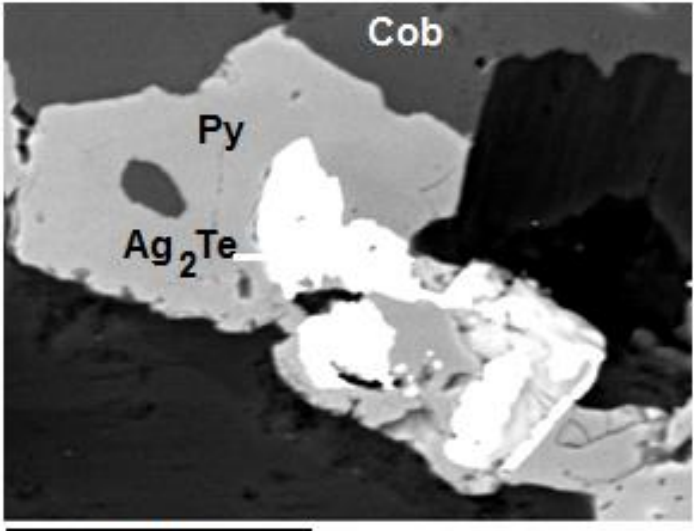

$14 \mu \mathrm{m}$

Pис. 7. Изображение в обратно-рассеянных электронах участков аншлифа незонального никелистого кобальтина, пирита и ульманнита (Ull)

Fig. 7. Back-scattered electron image of polished sections made from ore samples containing polished nickel-plated cobaltite, pyrite and ullmannite (Ull)

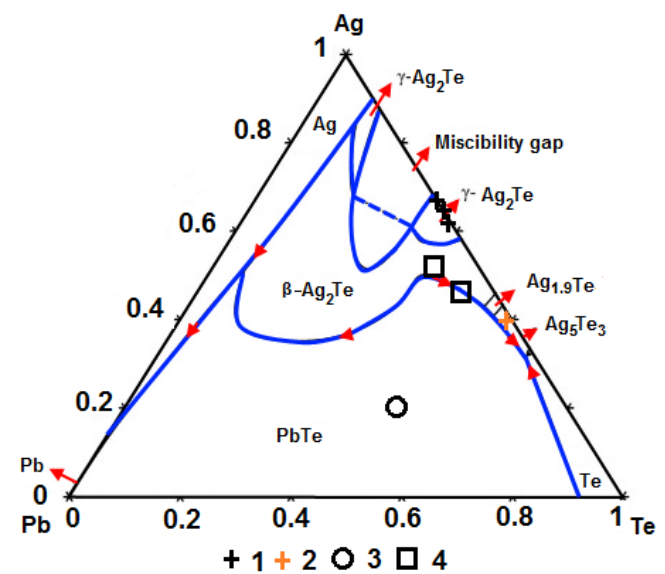

Теллурид серебра образует кристаллы двух модификаций: $\beta-\mathrm{Ag}_{2} \mathrm{Te}, \gamma-\mathrm{Ag}_{2} \mathrm{Te}$, что отчетливо можно наблюдать на диаграмме Ag-Pb-Te (ат. \%) (рис. 8) [13]. Он является одним из часто встречающихся микровключений, пространственно ассоциирующих с ми-
Fig. 8. Projection of the liquidus of the ternary $\mathrm{Ag}-\mathrm{Pb}-\mathrm{Te}$ system (at. \%) was projected onto experimental alloys [13]: 1, 2 - silver telluride $(\gamma-A g 2 T e): 1-A$ $<61,12 \%, 2-A g=21-11 \% ; 3$ - lead telluride PbTe (Pb 34,57-37,31\%), 4 - silver telluride ( $\beta$-Ag2Te) $(\mathrm{Pb} 7,84-8,90 \%)$

Puс. 8. Проекиии ликвидуса тройной системы Ag-Pb-Te (ат\%), спроечирована на экспериментальные сплавы [13]: 1, 2 - теллурид серебра $\left(\gamma-\mathrm{Ag}_{2} \mathrm{Te}\right)$ : $1-A g<61,12 \%, 2-A g=21-11 \% ; 3-$ теллурид свинца PbTe (Pb 34,57-37,31\%), 4 - теллурид серебра $\left(\beta-\mathrm{Ag}_{2} \mathrm{Te}\right)(\mathrm{Pb} 7,84-8,90 \%)$

нералами ряда кобальтин-герсдорфит, халькопиритом и нередко образует двухфазные кристаллы (рис. 9, D). Габитус кристаллов теллурида серебра пластинчатый, но чаще они образуют зернышки неправильной округлой формы размером не более 20 мкм. 

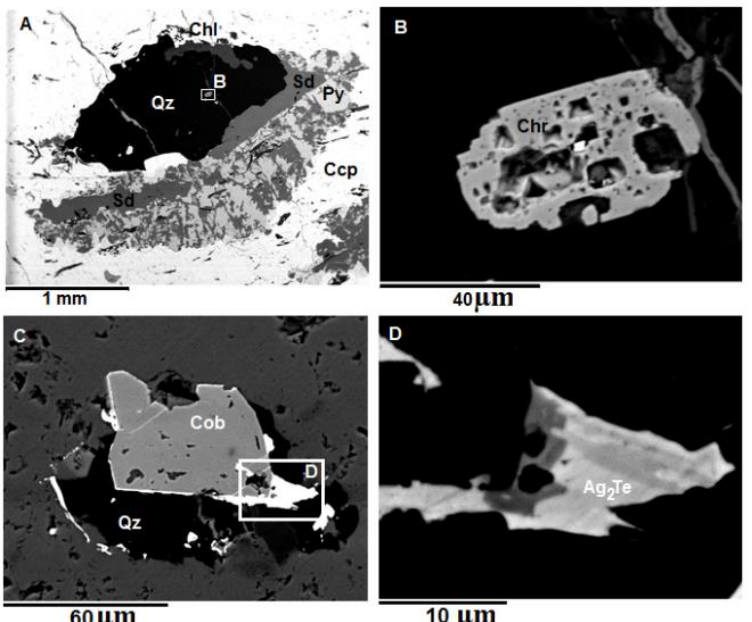

$10 \mu \mathrm{m}$

Рис. 9. Изображение в обратно-рассеянных электронах участков аншлифа микровключений рудных минералов медного колчедана: А) микровключение хромита в зерне квариа, заключенное в сидеритхлорит-сульфидную массу; В) скелетный кристалл хромита (Chr), в чентре высвечивается кристаллик редких земель; $C$, D) никелистый кобальтин обрастает теллуридом серебра; D) две фазы теллурида серебра

Fig. 9. Back-scattered electron image of polished sections made from ore samples containing microinclusions of ore minerals of copper pyrite: A) microinclusion of chromite in quartz grain enclosed in sideritechlorite-sulfide mass; B) skeletal crystal of chromite (Chr), in the center a crystalline of rare earths is highlighted; $C, D)$ nickel cobaltin is overgrown with silver telluride; D) two phases of silver telluride

$\beta-\mathrm{Ag}_{2}$ Те содержит примеси свинца $(<8,90 \% \mathrm{~Pb})$ и никеля $(<5,53 \% \mathrm{Ni})$ на фоне высоких концентраций элементов халькопирита, тогда как $\gamma-\mathrm{Ag}_{2} \mathrm{Te}$ не содержит свинца, а никель встречается спорадически, однако присутствует примесь мышьяка.

Теллурид свиниа (PbTe) содержит примесь никеля $(<2,50 \% \mathrm{Ni})$ при относительно высоком содержании серебра $(<15,62 \% \mathrm{Ag})$.

Галенит $(\mathrm{PbS})$ распространен гораздо реже, чем теллурид свинца. Он заполняет пустоты и трещины в халькопирите и сидерит-мусковит-хлоритовых сланцах, образуя округлые зерна не более 3 мкм в диаметре.

\section{Этапы рудообразования}

Учитывая состав руды проявления Майке и модель последовательности формирования PGE, редких минералов и сульфидов медноколчеданных руд, разработанную ранее $[14,15]$, можно предположить, что образование медноколчеданных руд Майке происходило в условиях магматических и постмагматических процессов минералообразования (рис. 10).

Вслед за $[16,17]$ можно предположить, что на ранней стадии из сульфидного расплава кристаллизовалась основная масса кристаллов платиносодержащих сульфоарсенидов и сперрилита, что типично для магматической стадии минералообразования, в этот расплав также были заключены небольшие кумулаты MSS, не содержащего благородных металлов.
В позднемагматическую или гидротермальную стадию (рис. 10, С) на минералы предыдущих стадий накладываются сульфиды цветных металлов, не образующие правильные кристаллографические формы. Это такие минералы, как тестибиопалладит, мелонит и вавринит, являющиеся основными источниками палладия.

В ассоциации с сульфоарсенидами никеля и кобальта крайне редко встречается ульманнит. Для него свойственен широкий спектр элементов-примесей: $\mathrm{Ag}$, $\mathrm{Pd}, \mathrm{Te}, \mathrm{Bi}$, что характерно для минеральных ассоциаций гидротермальных месторождений.

На этом этапе на медноколчеданные руды накладывается полиметаллическая минерализация. Сфалерит, как правило, сопровождается образованием акантита и самородного серебра. Наиболее поздними образованиями являются фосфаты и фторфосфаты REE.

Предполагаемая последовательность образования медноколчеданных руд карбонатитов линейнотрещинного типа косвенно подтверждается изотопным составом свинца колчеданно-полиметаллических месторождений Северного Улытау, изученным ранее О.Г. Кошевым [18]. Им было высказано, что изотопные составы свинца месторождений данного района указывают на сложную многостадийную историю формирования ряда месторождений Кургасынского района Северного Улытау путем смешивания древнего аномального свинца протерозойского возраста с обыкновенным свинцом, возникшим в последующие периоды тектономагматических активизаций в раннем палеозое [18].

Вероятнее всего, по такому типу формируется большинство месторождений карбонатитов, связанных с мантийными очагами изначально формирующихся над зонами субдукции. Их пространственная связь с зонами субдукции находит подтверждение присутствием $\mathrm{NaCl}$, рутила, апатита и монацита в изначально плутонических ультраосновных породах [19-21].

Завершается рудогенез образованием Nd-содержащих черчитовых кор выветривания.

\section{Заключение}

Распределение и формы нахождения $\mathrm{Au}$ и $\mathrm{Ag}$

Теллурид серебра является одним из часто встречающихся микровключений, пространственно ассоциирующих с минералами ряда кобальтингерсдорфит, халькопиритом и сфалеритом. Серебро в виде примеси также встречается в мелоните, где его концентрации достигают $12,37 \%$, а в ваврините содержание серебра не превышает 5,0 \%. Акантит $(87,00 \% \mathrm{Ag})$ повсеместно ассоциирует со сфалеритом, образуя внешние каймы.

Результаты атомно-эмиссионного полуколичественного спектрального анализа после химического обогащения показали, что медноколчеданные руды содержат до 15 г/т серебра. Уровень концентрации золота меньше 2 г/т. Самородное золото не обнаружено. 
A) $\quad 1200-1000^{\circ} \mathrm{C}$

Магматическая кристаллизация

Незональный

сульфоарсенид Сперрилит

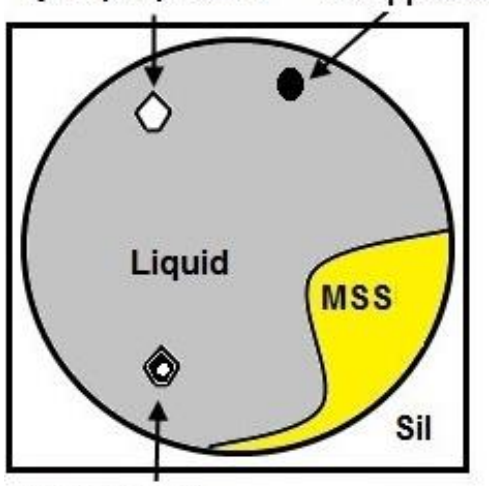

Зональный PGE-сульфоарсенид
B) $\quad<650^{\circ} \mathrm{C}$

\section{Эволюция сульфидов}

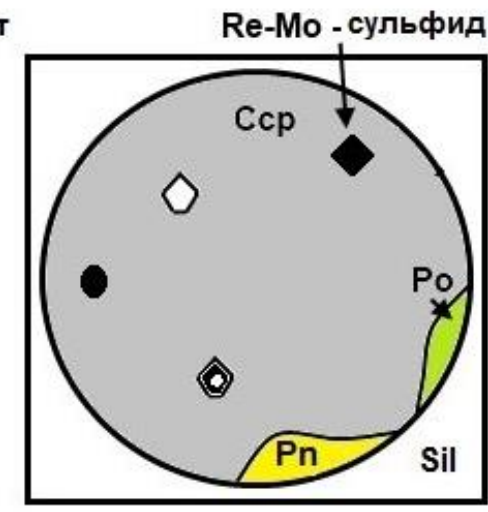

il

\section{D) Поздняя стадия деформа- ции/гидротермальная активизация}

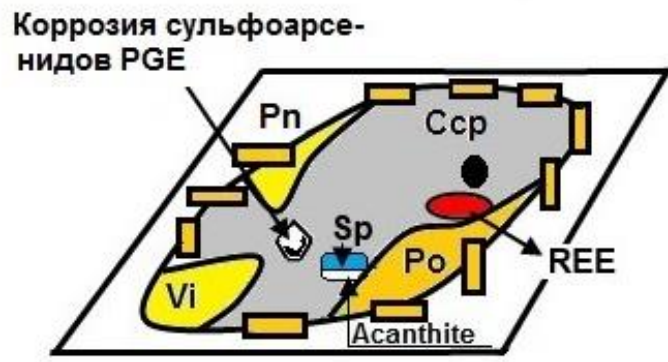

C) $\quad<540^{\circ} \mathrm{C}$

\section{Позднемагматическая/ гидротермальная активизация \\ Срастание вторичных силикатов с сульфидами}

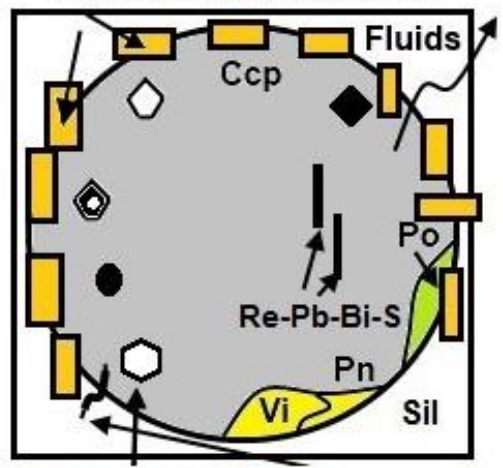

Тестибиопалладит растворяется или кристаллизуется

Рис. 10. Схематическая модель последовательности формирования $P G E$, редких минералов и сульфидов медноколчеданных руд месторождения Майке построена на основе материалов [14, 16]: А) ранняя кристаллизация мелких идиоморфных зональных $P G E$-сульфоарсенидов и сперрилита из сульфидной жидкости и их слияние в MSS (моносульфидный твердый раствор); В) эволюиия сульфидных минералов (пентландит, пирротин, халькопирит), включая сульфиды рения и молибденита, при охлаждении до температуры ниже $650{ }^{\circ} \mathrm{C}$; $C$ ) поздняя магматическая и/или гидротермальная активность и последующая рекристаллизация сульфидов основных металлов с вторичныли силикатами одновременно с образованием тестибиопалладита и Рb-Те-фаз либо в виде растворения сульфидов основных металлов, либо при кристаллизаиии из небольших объемов захваченного расплава; D) демобилизация сульфидов на поздней стадии в зонах разломов и коррозия существующих сульфоарсенидов PGE, образование акантита по сфалериту и образование по трещинам фторфосфатов и фосфатов редкоземельных элементов

Fig. 10. Schematic model of the sequence of formation of PGE, rare minerals and sulfide copper-sulphide ores from the Mayke deposit, built on the basis of the materials of the article [14, 16]: A) early crystallization of small idiomorphic zonal PGE-sulfoarsenides and sperrylite from sulphide liquid and their fusion in MSS; B) evolution of sulphide minerals (pentlandite, pyrrhotite, chalcopyrite), including rhenium sulphide and molybdenite sulphide, when cooled to $-650^{\circ} \mathrm{C}$; C) late magmatic and/or hydrothermal activity and the subsequent recrystallization of sulphides of base metals with secondary silicates simultaneously with the formation of testibiopalladite and Pb-Te phases either as dissolution of sulphides of the base metals, or during crystallization from small volumes of trapped melt; D) demobilization of sulphides at a later stage in fracture zones and corrosion of existing sulfoarsenides PGE, formation of acanthite on sphalerite and formation of rare-earth fluorophosphates and phosphates of rare earth elements

Распределение и формы нахождения платиновых металлов

В процессе минералогических исследований нам не удалось обнаружить совместного нахождения платины и палладия в одном рудном минерале.

Сульфоарсенид $\mathrm{Ni}$-Сo (никелистый кобальтин) является источником минералов $\mathrm{Pt}(3,93 \%), \operatorname{Ir}(4,93 \%)$, Rh $(0,35 \%), \mathrm{Ru}(1,94 \%)$; Os $(0,91 \%)$.
Распределение и формы нахождения редких

и редкоземельных элементов (Re, Te, Y, La, Ce, Nd, Sm, Er, Cd, C)

Рений (3,41-51,44 \% Re) обнаружен в составе сульфидов меди, железа, никеля, свинца и висмута, микровключения, которых заключены в халькопирит, и только сульфид рения $(50,46 \% \mathrm{Re})$, молибдена, меди и железа встречается совместно с пиритом. 
Теллур входит в состав таких минералов, как теллурид серебра, теллурид свинца, тестибиопалладит, мелонит и вавринит, их микровключения встречаются в халькопирите и минералах ряда кобальтингерсдорфит.

Иттрий, лантан, иерий встречаются в составе хромита в зернах кварца, заключенного в сидеритхлорит-сульфидную массу. Высокий уровень концентрации Y (30 г/T), La (30 г/T), Ce (70 г/т) также установлен и в кварц-рутил-сидерит-хлоритовых сланцах.

Алмаз крайне редко встречается в составе графитов карбонатитов Маятасского рудного района. Он ассоциирует с гранатом пиропо-альмандинового и пиропо-сперрилито-альмандинового ряда.

По результатам атомно-эмиссионного полуколичественного спектрального анализа медноколчеданные руды содержат: $\operatorname{Ag}(30$ г/т), Pt (<2 г/т), Ru (10 г/т),

\section{СПИСОК ЛИТЕРАТУРЫ}

1. Вишневская И.И., Трусова И.Ф. Западно-Улытауский пояс ультраосновных и основных пород // Геология и разведка. 1967. - № 11. - С. 32-43.

2. Чудин С.С.К проблеме платиноносности недр Казахстана // Горно-Геологический Журнал. - 2012. - № 3-4. - С. 31-32.

3. Бетехтин А.Г. Минералогия. - М.: Изд-во ГИГЛ, 1950. - 957 с

4. Нсанов Р.А. Иттрий-редкоземельное оруденение в корах выветривания Маятасского рудного поля (Северный Улытау): автореф. дис. ... канд. геол.-минерал. наук. - Алмата, 1993. $17 \mathrm{c}$.

5. Литвин Ю.А. Экспериментальные исследования физикохимических условий образования алмаза в мантийном веществе // Геология и геофизика. - 2009. - Т. 50. - № 12. C. $1530-1546$.

6. Материнские среды алмазов и первичных включений по данным физико-химического эксперимента / Ю.А. Литвин, П.Г. Васильев, А.В. Бобров, В.Ю. Окоемова, А.В. Кузюра // Геохимия. - 2012. - № 9. - С. 811-847.

7. Чудин С.С., Воинов В.Н. Природные фуллерены Северного Казахстана // Горно-Геологический Журнал. - 2003. - № 1. C. 7-10.

8. Кембаев М.К. Формы нахождения редких земель в корах выветривания месторождений Северного Казахстана и их 3D модели: диссертация на соискание степени доктора философии (PhD) - Алмата, 2017. - $111 \mathrm{c}$

9. Minerals of noble and rare elements in Karaturgay and Mayke ore types of Mayatas ore region (North Ulytau, Kazakhstan) / V.G. Stepanets, V.L. Levin, G.K. Bekenova, E.S. Li, N.M. Zhukov, M. Khakimzhanov // News NAN PR. Series of geology and technical. - 2019. - V. 2. - P. 21-29.

10. Зарайский Г.П. Зональность и условия образования метасоматических пород. - М.: Изд-во «Недра», 1989. - 344 с.

11. Месторождения свинца и цинка Казахстана. Справочник Х.А. Беспаев, К.М. Егембаев, Л.А. Мирошниченко, В.В. Колесников, С.А. Акылбеков, Г.Д. Ганженко. - Алматы, 1997. $152 \mathrm{c}$.

12. Карбонатиты и кимберлиты / А.А. Фролов, А.В. Лапин, А.В. Толстов, Н.Н. Зинчук, С.В. Белов, А.А. Бурмистров. - М.: Изд-во «НИА-Природа», 2005. - 540 с.
Ir $(10 \quad \Gamma / \mathrm{T}), \mathrm{Y}(10 \quad \Gamma / \mathrm{T})$, а также As $(0,015 \%), \mathrm{Pb}$ $(0,0015 \%), \mathrm{Cd}(0,001 \%) \mathrm{Bi}(0,0002 \%), \mathrm{Sb}(<0,002 \%)$, Мо $(0,0001 \%)$ при крайне высоких содержаниях $\mathrm{Cu}$ $(>1,0 \%)$ и $\mathrm{Zn}(0,2 \%)$

\section{Петрология рудовмещающих пород содержащих поликомпонентные медноколчеданные руды проявления Майке}

Парагенетическая ассоциация карбонатов, включая сидерит, апатита, титанита, альбита, кварца, граната (пироп-альмандинового ряда), хромсодержащего мусковита и обогащенного хромом клинохлора и их пространственная связь с графит-кварц-хлоритовыми сланцами позволяют рассматривать данные породы составной частью силицит-карбонат-углеродистого комплекса, отражающего состав ростового расплава мантийного происхождения.

13. The microstructure, liquidus projection and thermodynamic modeling of thermoelectric $\mathrm{Ag}-\mathrm{Pb}-\mathrm{Te}$ system / $\mathrm{H}$. Wu, W. Foo, W. Gierlotka, S. Chen // Materials Chemistry and Physics. 2013. - V. 141. - P. 758-767.

14. The timing and formation of platinum-group minerals from the creighton Ni-Cu-platinum-group element sulfide deposit, Sudbury, Canada: early crystallization of PGE-rich sulfarsenides / S.A.S. Dare, S.-J. Barnes, H.M. Prichard, P.C. Fisher // Economic Geology. - 2010. - V. 105. - P. 1071-1096.

15. Naldrett A. Magmatic sulfide deposits geology, geochemistry and exploration. - Berlin: Springer, 2004. - 728 p.

16. Mineralogy and geochemistry of $\mathrm{Cu}$-Rich ores from the McCreedy east Ni-Cu-PGE deposit (Sudbury, Canada): implications for the behavior of platinum group and chalcophile elements at the end of crystallization of a sulfide liquid / S.A.S. Dare, S.-J. Barnes, H.M. Prichard, P.C. Fisher // Economic Geology. - 2014. V. 109. - P. 343-366.

17. Carter W.M., Watkinson D.H., Jones P.C. Post-magmatic remobilization of platinum-group elements in the Kelly Lake Ni$\mathrm{Cu}$ sulfide deposit, Copper Cliff Offset, Sudbury // Exploration and Mining Geology. - 2001. - V. 10. - P. 95-110.

18. Кошевой О.Г. Изотопный состав свинца на полиметаллических и свинцово-цинковых месторождениях Центрального и Южного Казахстана в связи с их возрастом и генезисом: автореф. дис. ... канд. геол-минерал. наук. - Алма-Ата, 1984. $19 \mathrm{c}$.

19. Manning C.E. Fluids of the lower crust: deep is different // Annual Review of Earth and Planetary Sciences. - 2018. - V. 46. - P. 67-97.

20. Ayers J.C., Watson E.B. Solubility of apatite, monazite, zircon, and rutile in supercritical aqueous fluids with implications for subduction zone geochemistry philosophical transactions // Physical Sciences and Engineering. - 1991. - V. 335. - P. 365-375.

21. Практическая петрология: методические рекомендации по изучению магматических образований применительно к задачам госгеолкарт / М.В. Наумов, Е.А. Кухаренко, А.Е. Костин, Д.Н. Ремизов. - СПб.: Изд-во ВСЕГЕИ, 2017. - 168 с.

Поступила 01.05.2020 2.

\section{Информация об авторах}

Cтепанец B.Г., доктор естественных наук, главный геолог «Astra Mining Kazakhstan».

Левин В.Л., кандидат геолого-минералогических наук, ведущий научный сотрудник лаборатории минералогии ТОО «Институт геологических наук им. К.И. Сатпаева».

Ли E.C., магистр техники и технологии, докторант $\mathrm{PhD}$, старший преподаватель кафедры геологии и разведки месторождений полезных ископаемых Карагандинского государственного технического университета. 
Бекенова Г.К., доктор геолого-минералогических наук, руководитель лаборатории минералогии ТОО «Институт геологических наук им. К.И. Сатпаева», Казахстан.

Жуков Н.М., кандидат геолого-минералогических наук, ведущий научный сотрудник лаборатории региональной металлогении ТОО «Институт геологических наук им. К.И. Сатпаева».

Хакимжанов М.С., бакалавр, старший консультант SRK Consulting (Kazakhstan) Limited. 
UDC 549:552.323.6, 549:553.491

\title{
GEOLOGY AND MINERALOGY OF CARBONATITES OF LINEAR-CRACKED TYPE IN MAYKE ORE OCCURRENCE OF MAYATAS ORE REGION (NORTH ULYTAU)
}

\author{
Vladimir G. Stepanets ${ }^{1}$, \\ wladimir@stepanez.de \\ Vladimir L. Levin², \\ levin_v@inbox.ru \\ Elena S. Li ${ }^{3}$, \\ li_elena.kstu@mail.ru
}

\section{Galiya K. Bekenova²,} bekenova@mail.ru

Nikolay M. Zhukov², nik.zhukov.33@mail.ru

\author{
Marat S. Khakimzhanov ${ }^{4}$, \\ m.khakimzhanov@gmail.com \\ 1 Astra Mining Kazakhstan, \\ 207, Regent street, London, W1B3HH, UK. \\ 2 LLP «Institute of Geological Sciences K.I. Satpayev», \\ 69/94, Valikhanov street, Almaty, 050010, Kazakhstan. \\ 3 Karaganda State Technical University, \\ 56/2, Nursultan Nazarbaev street, Karaganda, 100008, Kazakhstan. \\ ${ }^{4}$ SRK Consulting (Kazakhstan) Limited, \\ 69/94, Valikhanov street, Almaty, 050010, Kazakhstan.
}

The relevance of the research consists in detailed mineralogical studies with a focus on electron probe microanalysis provide information on the composition of ores and the form of occurrence of noble metals (platinum groups), rare and rare earth elements, which can significantly affect the economic value of the Mayke ore occurrence.

The main aim of the research is to determine the distribution and forms of occurrence of noble, rare-earth and rare metals in multicomponent copper-pyritic ores of Mayke occurrence.

Objects: linear-cracked type metasomatites and pyrite-copper ore on the right bank of the Mayke River in the Mayatas ore region.

Methods. The composition of copper pyrite ores and rock-forming minerals of metasomatites was studied in the laboratories of mineralogy and physics-chemical researches of the Institute of Geological Sciences named after K.I. Satpayev (Almaty) using an INCA ENERGY dispersive spectrometer, OXFORD INSTRUMENTS. Atomic emission semi-quantitative spectral analysis, X-ray diffractometric and thermal analyzes were carried out.

Results. The paper considers the main criteria of petrography and mineralogy of metasomatites of linear-cracked type and genetically associated copper-pyrites, first identified within the Mayatas ore region. It is proved that the main ore bodies of copper pyrites are localized in quartz-rutile-siderite-chlorite and siderite-muscovite-chlorite schists, which are an integral part of the silicite-carbonate-carbon complex. Based on the detailed mineralogical studies, it was shown that copper-pyrite ores are sources of platinoids, rare earth elements and rhenium. The violarite, pyrite, sphalerite, pyrrhotite, microinclusions of cobaltin, nickel cobaltin, ferrocobaltin, gersdorfite, silver telluride, acanthite, lead telluride, galena, testibiopalladite, bismuthistite, are identified in the composition of copper-pyrite ores of Mayke occurrence. It is shown that zonal nickel cobaltin is a source of platinoids (Pt, Ir, Ru, Rh, Os) that form multicomponent solid solutions. Rhenium is a component of sulfides of copper, iron, nickel, lead and bismuth. Tellurium was found in silver telluride, lead telluride, testibiopalladite, melonite and wavrinite. Erbium is found in non-zonal nickel-containing cobaltin and violarite. Cadmium is found as an isomorphic impurity only in sphalerite. The elements of cerium (light - $\mathrm{La}, \mathrm{Ce}, \mathrm{Pr}, \mathrm{Nd}, \mathrm{Sm}$ ) subgroups and $\mathrm{Y}$ are included in the composition of phosphates, fluorophosphates and are the source of formation of aqueous phosphates in the oxidation zone of copper-pyrite ores of the Mayke occurrence.

Key words:

Ulytau, carbonatites, pyrite ores, sulfides, arsenides, antimonides, rhenium minerals.

\section{REFERENCES}

1. Vishnevskaya I.I., Trusova I.F. Zapadno-Ulytauskiy poyas ultraosnovnykh i osnovnykh porod [West Ulytau belt of ultrabasic and basic rocks]. Geologiya i razvedka, 1967, no. 11, pp. 32-43.

2. Chudin S.S To the problem of platinum mineral resources of Kazakhstan. Gorno-Geologicheskiy Zhurnal, 2012, no. 3-4, pp. 31-32. In Rus.
3. Betekhtin A.G. Mineralogiya [Mineralogy]. Moscow, GIGL Publ., 1950. $957 \mathrm{p}$

4. Nsanov R.A. Ittriy-redkozemelnoe orudenenie a korakh vyvetrivaniya Mayatasskogo rudnogo polya (Severny Ulytau). Avtoreferat Dis. Kand. Nauk [ Yttrium-rare-earth mineralization in the weathering crusts of the Mayatassky ore field (Northern Ulytau). Kand. Diss. Abstract]. Almata, 1993. 17 p. 
5. Litvin Yu.A Experimental studies of the physicochemical conditions for formation of diamond in mantle matter. Geologiya $i$ geofizika, 2009, vol. 50, no. 12, pp. 1530-1546. In Rus.

6. Litvin Yu.A., Vasilyev P.G., Bobrov A.V., Okoyemova V.Yu., Kuzyura A.V. Maternal environments of diamonds and primary inclusions according to the physicochemical experiment. Geokhimiya, 2012, no. 9, pp. 811-847. In Rus.

7. Chudin S.S., Voinov V.N. Natural fullerenes of Northern Kazakhstan. Gorno-Geologicheskiy Zhurnal, 2003, no. 1, pp. 7-10. In Rus.

8. Kembayev M.K. Formy nakhozhdeniya redkikh zemel v korakh vyvetrivaniya mestorozhdeniy Severnogo Kazakhstana i ikh $3 D$ modeli. Avtoreferat Dis. Dokt. nauk [Forms of finding rare earths in the weathering crusts of deposits in Northern Kazakhstan and their 3D models. Dr. Diss.]. Almata, 2017. 111 p.

9. Stepanets V.G., Levin V.L., Bekenova G.K., Li E.S., Zhukov N.M., Khakimzhanov M. Minerals of noble and rare elements in karaturgay and mayke ore types of Mayatas ore region (North Ulytau, Kazakhstan). News NAN PR. Series of geology and technical, 2019, vol. 2, pp. 21-29.

10. Zarayskiy G.P. Zonalnost i usloviva obrazovaniya metasomaticheskikh porod [Zoning and conditions for formation of metasomatic rocks]. Moscow, Nedra Publ., 1989. 344 p.

11. Bespayev Kh.A., Yegembayev K.M., Miroshnichenko L.A., Kolesnikov V.V., Akylbekov S.A., Ganzhenko G.D. Mestorozhdeniya svintsa i tsinka Kazakhstana. Spravochnik [Deposits of lead and zinc in Kazakhstan. Directory]. Almaty, 1997. 152 p.

12. Frolov A.A., Lapin A.V., Tolstov A.V., Zinchuk N.N., Belov S.V., Burmistrov A.A. Karbonatity $i$ kimberlity [Carbonatites and kimberlites]. Moscow, NIA-Priroda Publ., 2005. 540 p.

13. Wu H., Foo W., Gierlotka W., Chen S. The microstructure, liquidus projection and thermodynamic modeling of thermoelectric $\mathrm{Ag}-\mathrm{Pb}-\mathrm{Te}$ system. Materials Chemistry and Physics, 2013, vol. 141, pp. 758-767.

14. Dare S.A.S., Barnes S.-J., Prichard H.M., Fisher P.C. The timing and formation of platinum-group minerals from the creighton $\mathrm{Ni}$ -
Cu-platinum-group element sulfide deposit, Sudbury, Canada: early crystallization of PGE-rich sulfarsenides. Economic Geology, 2010, vol. 105, pp. 1071-1096.

15. Naldrett A. Magmatic Sulfide Deposits Geology, Geochemistry and Exploration. Berlin, Springer, 2004. 728 p.

16. Dare S.A.S., Barnes S.-J., Prichard H.M., Fisher P.C. Mineralogy and geochemistry of $\mathrm{Cu}$-rich ores from the McCreedy east $\mathrm{Ni}-\mathrm{Cu}-$ PGE deposit (Sudbury, Canada): implications for the behavior of platinum group and chalcophile elements at the end of crystallization of a sulfide liquid. Economic Geology, 2014, vol. 109, pp. 343-366.

17. Carter W.M., Watkinson D.H., Jones P.C. Post-magmatic remobilization of platinum-group elements in the Kelly Lake Ni-Cu sulfide deposit, Copper Cliff Offset, Sudbury. Exploration and Mining Geology, 2001, vol. 10, pp. 95-110.

18. Koshevoy O.G. Izotopny sostav svintsa na polimetallicheskikh $i$ svintsovo-tsinkovykh mestorozhdeniyakh Tsentralnogo i Yuzhnogo Kazakhstana v svyazi s ikh vozrastom i genezisom. Avtoreferat Dis. Kand. nauk [The isotopic composition of lead in the polymetallic and lead-zinc deposits of Central and Southern Kazakhstan due to their age and genesis. Kand Diss. Abstract]. Alma-Ata, 1984. 19 p.

19. Manning C.E. Fluids of the lower crust: deep is different. Annual Review of Earth and Planetary Sciences, 2018, vol. 46, pp. 67-97.

20. Ayers J.C., Watson E.B. Solubility of apatite, monazite, zircon, and rutile in supercritical aqueous fluids with implications for subduction zone geochemistry philosophical transactions. Physical Sciences and Engineering, 1991, vol. 335, pp. 365-375.

21. Naumov M.V., Kukharenko E.A., Kostin A.E., Remizov D.N. Practical petrology: guidelines for the study of magmatic formations as applied to the tasks of state geological maps. St. Petersburg, VSEGEI Publ., 2017. 168 p.

Received: 1 May 2020.

\section{Information about the authors}

Vladimir G. Stepanets, Dr. Sc., chief geologist, Astra Mining Kazakhstan.

Vladimir L. Levin, Cand Sc., leading researcher, Institute of Geological Sciences K.I. Satpayev.

Elena $\mathbf{S}$. Li, master student, Karaganda State Technical University.

Galiya K. Bekenova, Dr. Sc., head of the Laboratory of Mineralogy, Institute of Geological Sciences K.I. Satpayev.

Nikolay M. Zhukov, Cand Sc., leading researcher, Institute of Geological Sciences K.I. Satpayev.

Marat S. Khakimzhanov, senior consultant, SRK Consulting (Kazakhstan) Limited. 